\title{
Securing Jobs in Times of Recession. The German Experience during the Financial Crisis 2008/2009*
}

\author{
MARTIN DIETZ \\ IAB (Institute for Employment Research), GERMANY.E-mail: Martin.Dietz@iab.de \\ MICHAEL STOPS \\ IAB (Institute for Employment Research), GERMANY.E-mail: Michael.Stops@iab.de \\ ULRICH WALWEI \\ IAB (Institute for Employment Research), GERMANY.E-mail: Ulrich.Walwei@iab.de
}

\begin{abstract}
As a consequence of the global financial crisis Germany experienced the deepest slowdown of its economy since World War II. However, given the sharp decrease of GDP the German labour market was quite stable compared to previous recessions when the labour market response was stronger. Therefore, there are empirical indications for temporary labour hoarding and it can be shown that the most significant factor for securing jobs was a reduction of working time. At the beginning of the crisis the conditions for short-time work became more attractive to firms. Therefore, non-subsidised forms of working time reductions or labour hoarding were complemented by public subsidies in the form of short-time work.
\end{abstract}

Keywords: Labor Hoarding, Economic Crisis, Employment, Public Policy.

\section{Asegurando los puestos de trabajo en tiempos de recesión. La experiencia alemana durante la crisis financiera $2008 / 2009$}

\begin{abstract}
RESUMEN
Como consecuencia de la crisis financiera mundial, Alemania ha experimentado la crisis económica más intensa desde la Segunda Guerra Mundial. Si embargo, dado el brusco descenso del PNB, el mercado de trabajo alemán ha permanecido bastante estable en comparación con periodos recesivos previos, en los cuales la respuesta del mercado de trabajo fue mayor. La evidencia empírica muestra una acumulación temporal de trabajo en las empresas y que el factor más relevante que ha asegurado los puestos de trabajo ha sido la reducción del tiempo de trabajo. Al comienzo de la crisis, las condiciones para las reducciones de jornada se volvieron atractivas para las empresas. Por tanto, formas no subvencionadas de reducción del tiempo de trabajo o de acumulación de mano de obra se vieron complementadas con subvenciones públicas en forma de programas de reducción de jornada.
\end{abstract}

Palabras clave: Acumulación de trabajo, crisis económica, empleo, políticas públicas.

JEL Classification: J21, J23, J38

\footnotetext{
* We thank the International Labour Organisation (ILO) for funding our research on the effects of the financial crisis on the German labour market.
}

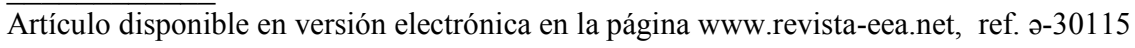




\section{INTRODUCTION}

Due to the financial crisis in 2009 economic activity in Germany decreased at a size which has not been observed since World War II. In particular exportoriented firms in manufacturing faced a shrinking demand and therefore an underutilisation of capital and labour. However, with respect to the dramatic decreese in GDP the German labour market remained to be quite robust. Compared with other countries the German labour market performed much better during the crisis and the present period of recovery. Although the German GDP went down more sharply than in G7-countries 1 as a whole the reduction in employment and the increase in unemployment were significantly lower (see Figures 1 and 2). In addition, recently the German labour market situation has improved again (Fuchs et al. 2010, Fuchs et al. 2011).

Figure 1

GDP and employment in G7 countries and Germany

1st quarter 2005 - 1st quarter 2010

(growth rates compared to the previous quarter in per cent, seasonally adjusted)

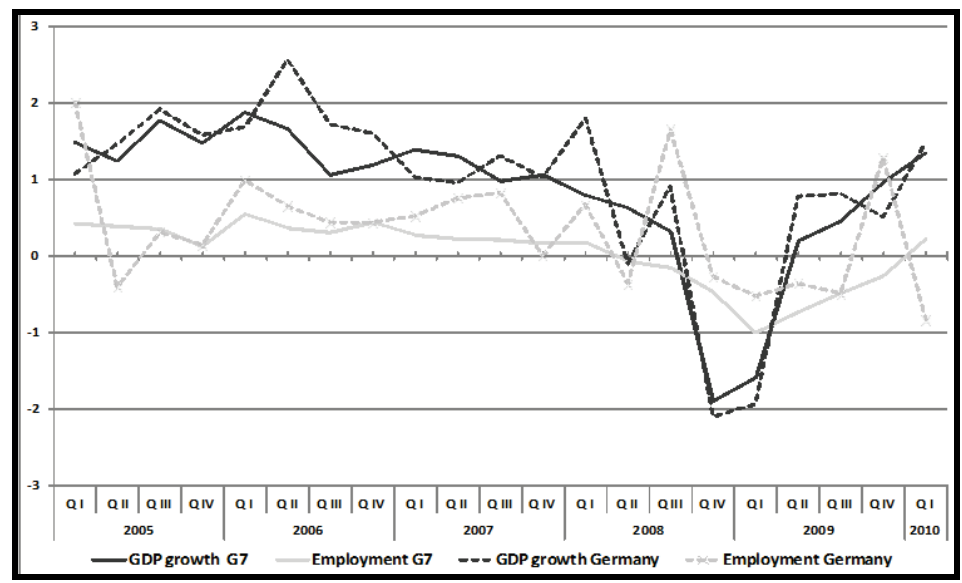

Source: OECD, own calculations.

This article sheds light on the transmission of the economic crisis to the German labour market. It is of special interest to investigate how Germany, often characterised as the "sick man of Europe" - a country that served as a textbook example for an overregulated labour market, managed to achieve its "German miracle". ${ }^{2}$

\footnotetext{
${ }^{1}$ Canada, France, Germany, Italy, Japan, United Kingdom, and the United States belong to the G7.

${ }^{2}$ See for example Paul Krugman's column in the New York Times at http://www.nytimes.com/ 2009/11/13/opinion/13krugman.html?_r=1\&pagewanted=print.
} 
Figure 2

GDP and unemployment in G7 countries and Germany 1st quarter 2005 - 1st quarter 2010

(growth rates compared to the previous quarter in per cent, seasonally adjusted)

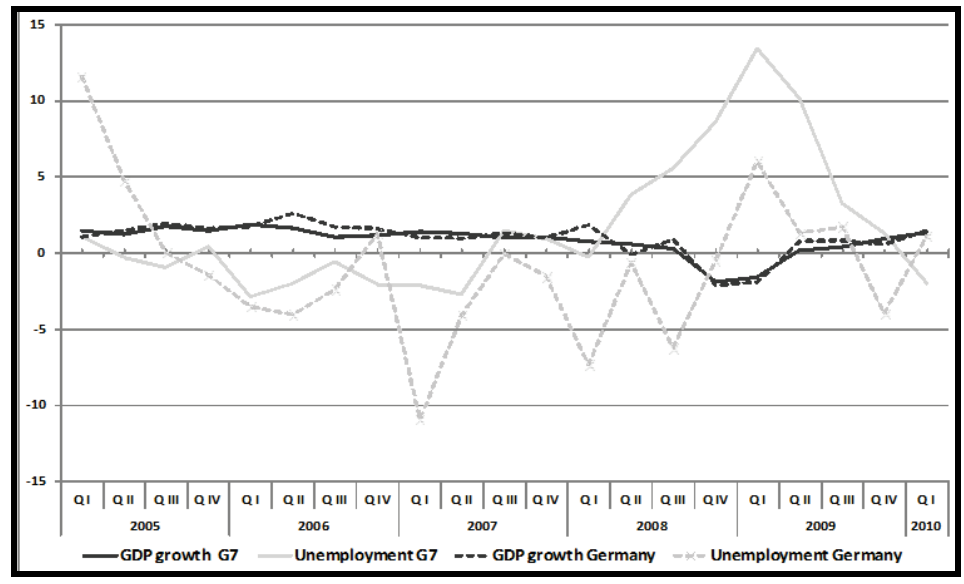

Source: OECD, own calculations.

To get explanations for the miracle it is necessary to refer at first to the specific features of the German labour market. In section 2 we describe the effects of the crisis by using different labour market aggregates. We will also analyse to which degree the crisis hit different regions, industries, and work arrangements such as part-time work or temporary employment. As we will see working time reductions are of special relevance for the recent labour market development in Germany. Therefore, in section 3 we ask how the immense reduction of working time was achieved. As it turns out, firm specific measures of internal flexibility have been supported by social dialogue on the company level and on the collective level. The government complemented internal measures of flexibility by providing more generous short-time work schemes to subsidise working time reductions and thereby helped securing jobs. As being the most important policy instrument in the crisis, we will analyse the conditions and the utilisation of short-time work in greater detail. In line with the reduction of working hours we also find a strong decline in labour productivity per head. In addition, labour productivity per hour decreased. This means that firms did not adjust employment in line with the decline in the demand for their products which can be seen as an indicator for labour hoarding. Therefore, we will discuss the attractiveness of internal compared to external adjustments and the rationale for labour hoarding on the firm level. At the end of the section we will ask whether there might also be some negative side effects resulting from the strong use of internal flexibility measures. The conclusion presents a summary of the main findings and asks for lessons from the German case. 


\section{LABOUR MARKET IMPACTS OF THE CRISIS}

The financial crisis hit the German economy at a time when the labour market was booming. Labour market indicators clearly show a much better performance during the last boom than during the previous upswing. Figure 3 shows that the employment situation improved considerably compared to the former upswing from 1998 to 2001. Especially the increase in employment covered by social security contributions was much higher, while the earlier upswing showed a high proportion of additional marginal part-time employment (so-called Mini-Jobs). This difference also becomes visible when looking at the higher increase in total hours worked from 2005 to 2008.

Figure 3

Employment intensity of the last boom periods (percentage changes)

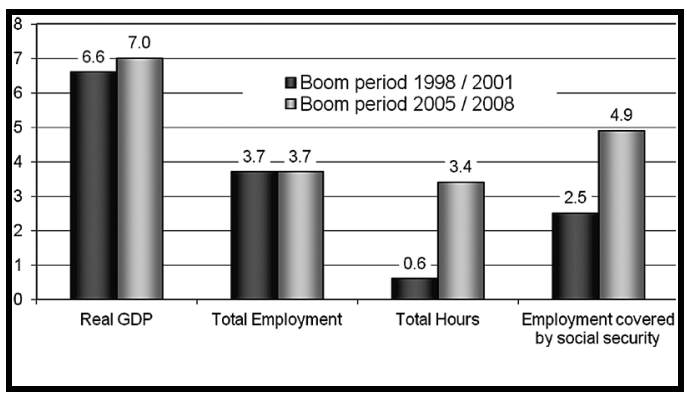

Source: Federal Statistical Office, IAB.

The much better labour market performance in terms of total hours as well as employment covered by social security during the last upswing was not solely due to the small difference in economic growth. It can be seen as an indication for the impacts of labour market reforms. The so-called Hartz-reforms were implemented between 2002 and 2005. They included several measures such as a deregulation of non-standard work arrangements, a lowering of unemployment benefits particularly for long-term recipients and a more effective use of active labour market policies. Recent analyses indicate that due to the reforms matching efficiency has been improved and work incentives have been strengthened (Gartner/Klinger 2008; Fahr/Sunde 2009; Klinger/Rothe 2010). Employers report that the willingness of workers to accept less attractive jobs and work conditions increased (Kettner/Rebien 2007). This might also be one explanation why the quality of employment gains in the last boom was heterogeneous. Nonstandard work arrangements such as part-time employment, fixed-term contracts and agency work as well as low wage employment increased further (Arlt et al. 2010). 
Continuous wage moderation has also to be mentioned as another reason for the positive employment effects of the last boom. 3 The moderate development of labour costs reflects persistently high unemployment in Germany since the early 1990s and has been the result of an increasingly lower coverage of collective agreements as well as comprehensive labour market reforms. Wage moderation strengthened the competitiveness of German companies on the world markets and transferred the positive stimulus on the goods markets into new jobs and not just into wage increases. Also low-skilled workers and long-term unemployed benefitted and structural employment decreased for the first time since decades (Gartner/Klinger 2008).

Figure 4

Development of seasonally adjusted employment (subject to social security contributions) and seasonally adjusted unemployment in Germany (March 2007 - March 2010)

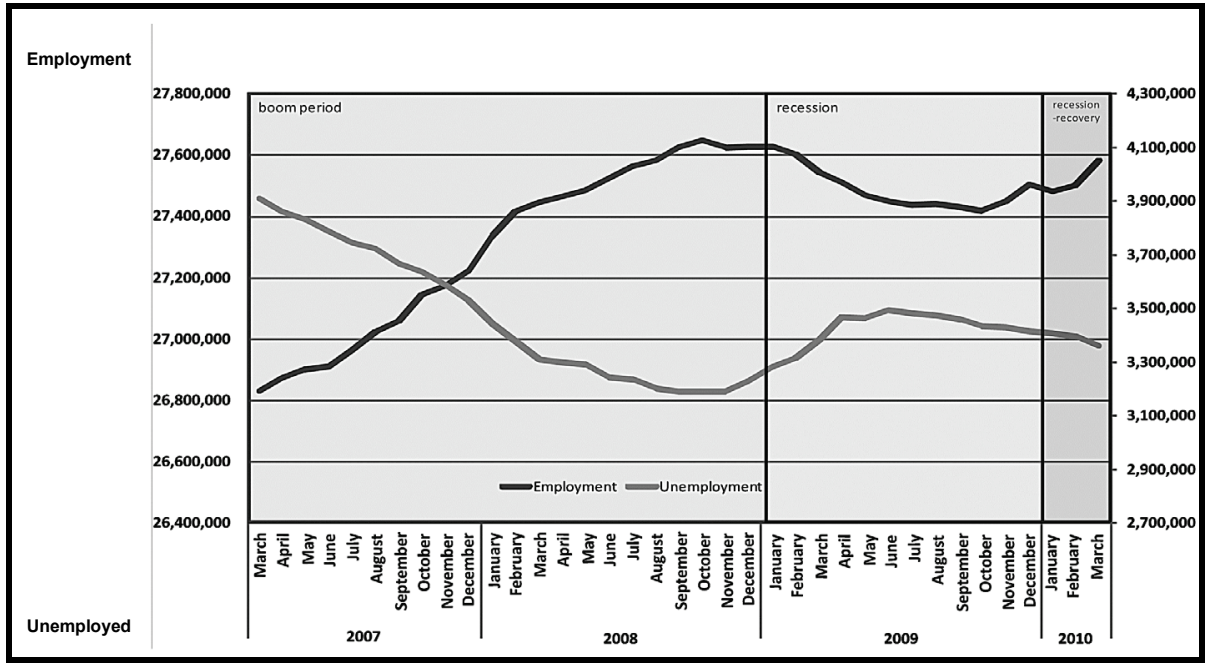

Source: Statistics of the Federal Employment Agency.

Companies faced a shrinking demand and a considerable underutilisation of capital and labour. Due to the large importance of export-oriented manufacturing for the German economy GDP decreased by 4.7 per cent in 2009. The crisis stopped the continuous labour market improvement which lasted until the third quarter of 2008. Until the second quarter of 2009 seasonally adjusted employment went down and seasonally adjusted unemployment went up. However, since then we observe a significant recovery: production and the volume of

\footnotetext{
${ }^{3}$ See also section 3.4 for a further discussion of wage moderation.
} 
orders and employment have been increasing and unemployment has been decreasing (see Figure 4).

Overall employment and unemployment are highly aggregated labour market figures which show a strong degree of stability bearing in mind the sharp decline in GDP. But as we will show there is some variation behind the overall picture of stability with regard to sector developments, work arrangements and hours worked.

\section{Employment by sectors and regions}

The labour market effects due to the financial crisis were not distributed equally. Not surprisingly asymmetrical sector effects as well as asymmetrical regional effects can be observed. Job losses particularly took place in two industries: manufacturing and the related sector Financing/Housing/Business-Related Service (see Figure 5). Between 3rd quarter 2008 and 1st quarter 2010 employment in manufacturing went down continuously by 6 per cent or about 450 thousands and - although employment in the sector Financing/Housing/ Business-Related Service increased from 4th quarter 2009 - this sector lost employment at a size of roughly 2 per cent or nearly 120 thousands.

Figure 5

Employment by Sectors

1st quarter 2005 - 1st quarter 2010

(Index: 1st quarter $2005=100$ )

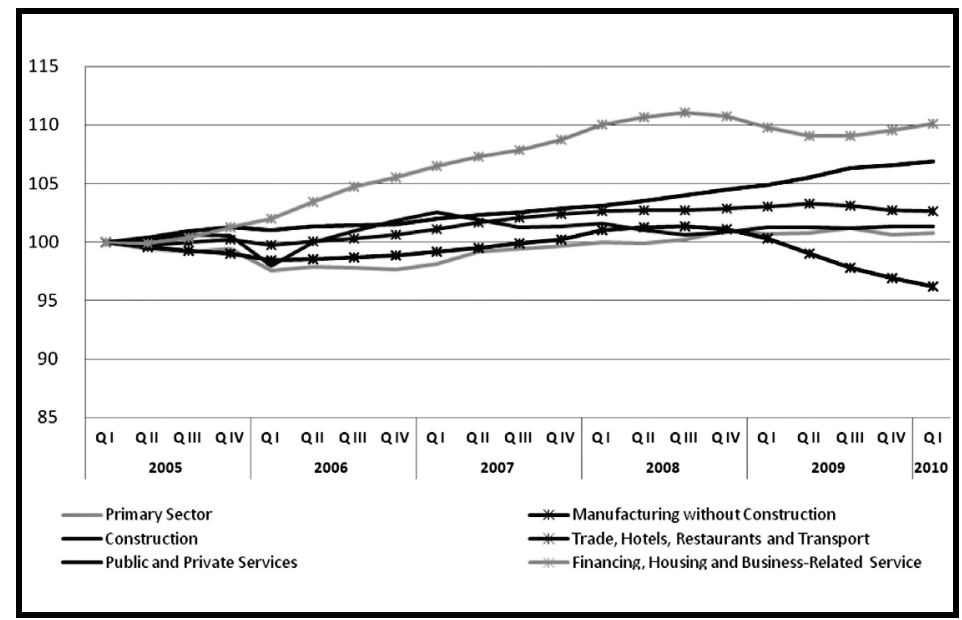

Source: Federal Statistical Office, own calculations.

The world-wide dimension of the shock implied that in particular exportoriented firms in manufacturing (especially in the sectors machinery, metal 
production and processing, chemicals) were facing a shrinking demand. These firms were highly competitive prior to the crisis and often situated in prospering regions in the south-western parts of Germany (Möller 2009). Figure 6 illustrates the asymmetric effects of the crisis. The left map marks regions with a low unemployment rate in green. The right map indicates that the crisis led to increasing unemployment rates in the same regions (dark red colours). On the other hand regions with higher unemployment (red colours in the left map) and a stronger service orientation as we observe them in Eastern Germany were not affected that severely by the crisis (green or yellow colours in the right map).

As a consequence the crisis triggered a certain convergence of unemployment rates in Germany (Schwengler/Loibl 2010). However, with respect to structural differences between the regions this convergence will only be a transitional phenomenon.

In any case the asymmetric consequences of the crisis were advantageous for the German labour market. Existing disparities were not fortified and structural unemployment did not become more severe. Many firms affected by the crisis had the financial power and the incentive to counteract the consequences of the crisis by their own efforts.

Figure 6

Unemployment rates in October 2009 and percentage changes compared to October 2008

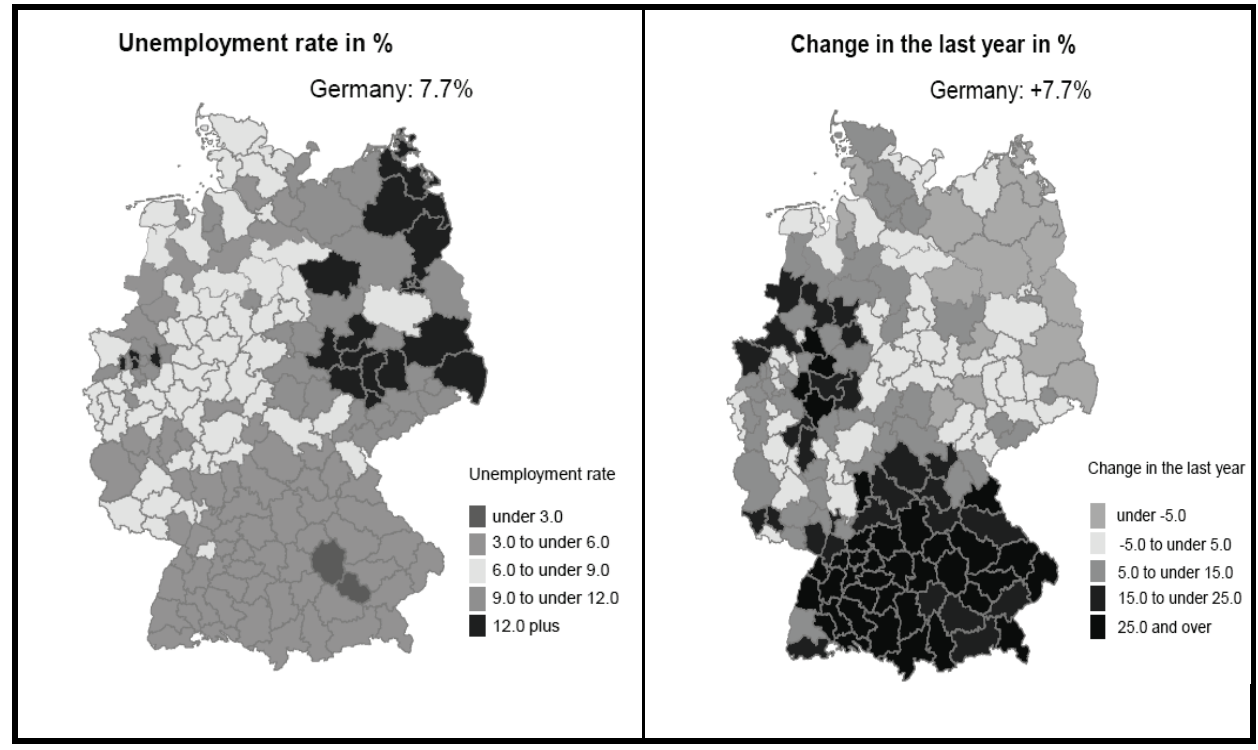

Source: Federal Employment Agency. 


\section{Work arrangements}

As already mentioned the sector Financing/Housing/Business-Related Services was largely affected by job losses due to the financial crisis. One specific and quantitatively important area of this sector is agency work which declined significantly since the beginning of the financial crisis. For firms agency work offers a high degree of numerical flexibility according to fluctuations in demand. While agency workers are statistically counted in the Financing/Housing/Business-Related Service sector, manufacturing companies use agency work more often than service companies and public employers (Crimmann et al. 2009). Since the 1990s agency work continuously increased. Deregulation of agency work took place several times (Antoni/Jahn 2009). As part of the Hartzreforms a major change was implemented in 2004. At the end of the last upswing in 2008, the level of agency work reached its present peak (see Figure 7). As a consequence of the financial crisis and its impact on manufacturing agency work dropped dramatically. So, agency work can be seen as a flexibility reserve that protects the core workers to a certain extent. Currently the number of agency workers is increasing again.

Figure 7

Agency work in Germany

$1993-2009$

(Total numbers and rate of employment covered by social security)

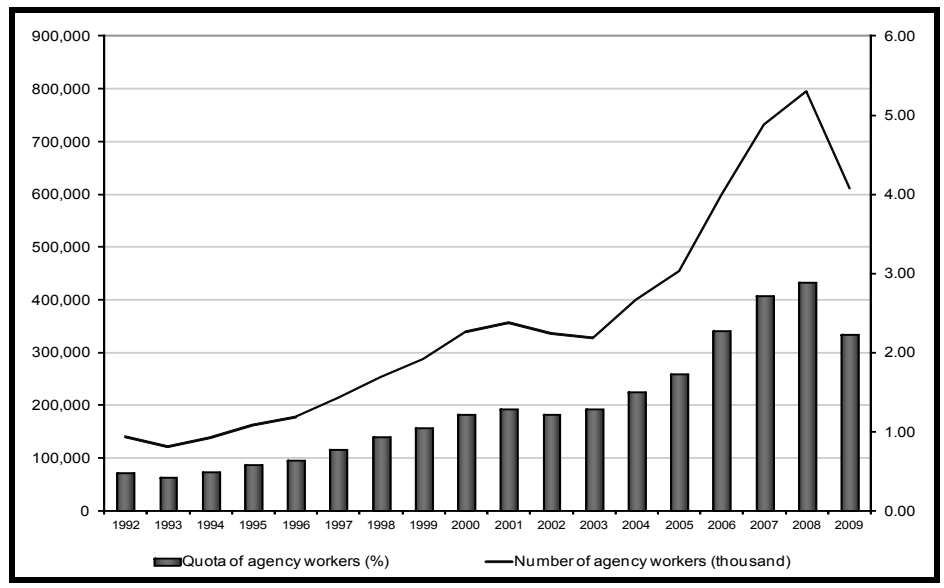

Source: Statistics of the Federal Employment Agency.

Compared with agency work fixed-term contracts as a share of all employed have been reduced at a much lower extent. The share of fixed-term contracts as part of all dependent employed dropped from 9.3 per cent in 2008 to 8.8 per cent in 2009 as data from the German establishment panel show. This can also 
be explained by the sector composition of fixed-term contracts, which are mainly used in the service sector less affected by the financial crisis. In addition, fixed-term contracts are not offering numerical flexibility to an extent agency works does but often serve as a prolonged probationary period. In doing so they are a stepping stone to standard-work arrangements - almost half of all fixed-term contracts in Germany lead into permanent employment (Hohendanner 2010).

The sector effects of the crisis also influence the composition of work arrangements in another respect. Part-time employment increased further from 33.8 per cent in 2008 to 34.6 per cent in 2009 . This development is partly due to job losses in manufacturing with a typically high share of full-time employment and job gains in services where a higher share of part-time employment is common. A shift-share analysis ${ }^{4}$ shows that approximately one third of the decrease of full-time employment can be associated with the shift of employment from manufacturing to services and the remainder is explained by the change in the composition of full-time and part-time jobs (Table 1). Part-time work increased due to a positive share effect which exceeds the negative shift effect by far.

\section{Table 1}

Changes in full- and part-time employment in Germany 1st quarter 2008 - 1st quarter 2010

(Shift effect as a percentage of total change in thousands)

\begin{tabular}{|c|c|c|c|c|c|}
\hline & & $\begin{array}{c}1^{\text {st }} \text { Quarter } \\
2008\end{array}$ & $\begin{array}{c}1^{\text {st }} \text { Quarter } \\
2008 / \text { Share }\end{array}$ & $1^{\text {st }}$ Quarter 2010 & $\begin{array}{c}1^{\text {st }} \text { Quarter } \\
2010 / \text { Share }\end{array}$ \\
\hline \multicolumn{2}{|l|}{ Part-time } & 12106 & 0.34 & 12338 & 0.35 \\
\hline \multicolumn{2}{|l|}{ Full-time } & 23609 & 0.66 & 23113 & 0.65 \\
\hline \multicolumn{2}{|l|}{ Total } & 35715 & 1 & 35451 & 1 \\
\hline & & $\begin{array}{c}\text { Shift } \\
\text { Effect }\end{array}$ & $\begin{array}{l}\text { Share } \\
\text { Effect }\end{array}$ & $\begin{array}{c}\text { Interaction } \\
\text { Effect }\end{array}$ & Total Effect \\
\hline \multirow{2}{*}{ Part-time } & Total & -89.49 & 323.88 & -2.39 & 232 \\
\hline & $\%$ of total effect & $-38.6 \%$ & $139.6 \%$ & $-1.0 \%$ & $100.0 \%$ \\
\hline \multirow{2}{*}{ Full-time } & Total & -174.51 & -323.88 & 2.39 & -496 \\
\hline & $\%$ of total effect & $-35.18 \%$ & $-65.30 \%$ & $+0.48 \%$ & $100.00 \%$ \\
\hline
\end{tabular}

Level of Employment $\left(1^{\text {st }}\right.$ Quarter 2010) = Shift Effect + Share Effect + Interaction Effect + Level of Employment $\left(1^{\text {st }}\right.$ Quarter 2008)

Source: IAB, own calculations.

\footnotetext{
${ }^{4}$ A shift-share analysis (Dunn 1960) deconstructs the changes in employment from $1^{\text {st }}$ quarter 2008 to $1^{\text {st }}$ quarter 2010 by holding the composition of full and part-time employment constant.
} 


\section{Labour turnover}

Typically recessions are associated with a slowdown of labour turnover. This is true for the downswing between 2001 and 2005 as well as for the recent financial crisis (see Figure 8). In addition, the data indicate that the level of labour turnover decreased over time. There might be two reasons for this trend: First, firms may be aiming at more employment stability of qualified core workers because they are aware of labour shortages which are increasingly visible in boom periods and may be even more severe in the foreseeing future due to demographic change and the expected shrinkage of the labour force. Second, workers may be risk averse and tending to avoid job changes due to labour market reforms which particularly reduced the level of unemployment benefits for long-term beneficiaries.

Figure 8

GDP and labour turnover rate* in Germany

1st Quarter 1996 - 4th Quarter 2009

(Growth rates compared to the previous quarter and turnover rate per quarter)

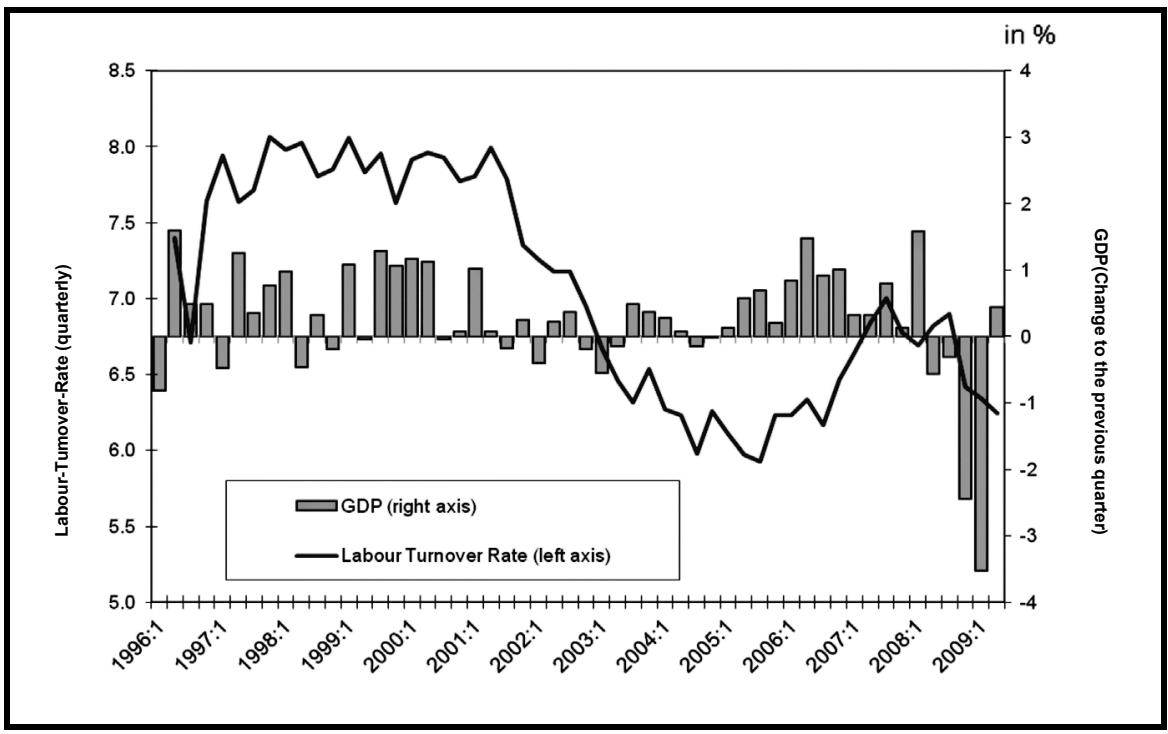

* The labour turnover rate relates the sum of recruitments and terminations to the absolute number of employed persons and thus is a measure for labour market dynamics.

Source: Statistics of the Federal Employment Agency; Thomas Rothe (IAB).

Flow analyses further show that job losses related to the crisis were not mainly due to an increased level of terminations but to a significantly lower level of recruitments (see Figure 9). Recent surveys indicate that companies which are affected by the crisis state that their most important response to a 
lacking demand is to reduce hiring (Heckmann et al. 2009, Möller 2009). Indeed an analysis of labour market flows shows that there were only minor entries to the labour market during the crisis (Rothe 2010). ${ }^{5}$ This negatively affects outsiders because the labour market cannot absorb as much job seekers as it did prior to the crisis. This is particularly relevant for unemployed who are trying to enter the labour market.

Figure 9

Recruitments and terminations in Germany

1st quarter 1997 - 4th quarter 2009

(thousands per quarter)

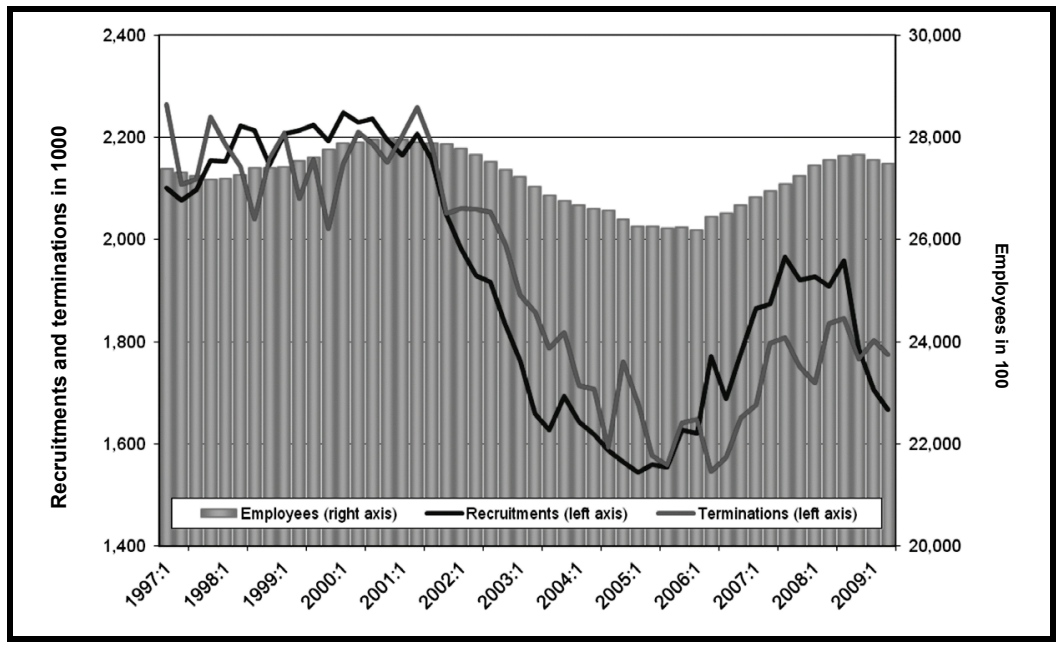

Source: Statistics of the Federal Employment Agency; Thomas Rothe (IAB).

\section{Development of Working Hours}

Up to now we have concentrated on labour market impacts with regard to the level of employment that all in all did not decrease in line with GDP in the course of the crisis. Nevertheless it is not clear that the volume of work did not considerably decrease either. Therefore the latter findings shall be complemented by an analysis of the changes in working hours.

Figure 10 depicts the development of GDP, employment, and total hours worked. It shows for Germany that employment and total hours worked are less volatile than output, while employment measured in total hours worked is more volatile than employment measured in heads. This is true for the period between 1991 and 2009 but in particular when considering the consequences of the

\footnotetext{
${ }^{5}$ See also Cazes et al. (2009) for a discussion with respect to the situation in the United States.
} 
financial crisis. With respect to the increasing costs of external flexibility, firms face incentives to increase internal work flexibility by varying working hours or the intensity of labour input over the business cycle.

Figure 10

GDP, employment and total hours worked in Germany 2nd quarter 1991 - 2nd quarter 2010

(Growth rates compared to the previous quarter in per cent, seasonally adjusted)

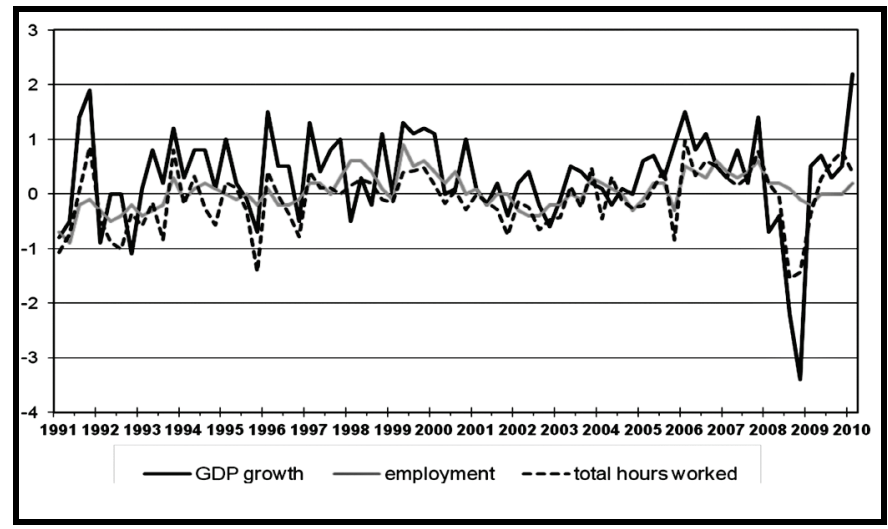

Source: Federal Statistical Office, IAB, own calculations.

Total hours worked can be decomposed into total employed and average hours worked per employed. Since the German reunification there has never been a reduction of average hours worked per employee like in the year 2009.

There are different developments of working hours on the industry level. Table 2 reveals that most industries were not affected by considerable changes in hours worked between 2007 and the $4^{\text {th }}$ quarter 2009. However, there is one important exception. In manufacturing total hours worked ( -9.0 per cent) as well as working hours per salaried worker (-8.0 per cent) decreased to a large extent. Comparing the $2^{\text {nd }}$ quarter 2009 with the same quarter of the previous year the response was even stronger. During this period which particularly covers the peak of the economic slowdown total hours worked in manufacturing went down by 14.7 per cent whereas average hours worked per salaried worker decreased by 12.4 per cent.

Of special importance in this context is the change in working hours of salaried workers. Not only because salaried workers represent nearly 90 per cent of the employed. In addition, average working hours of self-employed and related family workers decreased much more slightly between 2008 and 2009 than of salaried workers. Whereas the average working hours of self-employed and related family workers went up by 9.9 hours (from 2,038.8 hours in 2008 to 
2,048.7 hours in 2009) the average working hours of salaried workers (including multiple job holders) were reduced by 41.3 hours (see Table 2 ).

Table 2

Total hours worked and average hours worked per employee by industries in Germany 2007 - 2009

(Growth rates compared to previous year in per cent)

\begin{tabular}{|c|c|c|c|c|c|c|c|}
\hline \multicolumn{8}{|c|}{ Total Hours Worked in Mill. hours } \\
\hline & Total & $\begin{array}{c}\text { Primary } \\
\text { Sector }\end{array}$ & Manufacturing & Construction & $\begin{array}{l}\text { Trade, Hotel, } \\
\text { Restaurants } \\
\text { and Transport }\end{array}$ & \begin{tabular}{|c|} 
Finance, \\
Housing and \\
Business- \\
Related \\
Service
\end{tabular} & $\begin{array}{l}\text { Public and } \\
\text { Private } \\
\text { Services }\end{array}$ \\
\hline 2007 & 56,789 & \begin{tabular}{l|l}
1,482 \\
\end{tabular} & 11,533 & 3,680 & 14,105 & 9,797 & 16,191 \\
\hline 2008 & 57,450 & 1,502 & 11,587 & 3,686 & 14,218 & 10,108 & 16,349 \\
\hline 2009 & 55,985 & 1,477 & 10,493 & 3,653 & 13,932 & 9,876 & 16,553 \\
\hline \multicolumn{8}{|c|}{ Average Hours Worked per Employee } \\
\hline 2007 & $1,353.8$ & $1,452.9$ & $1,430.0$ & $1,532,9$ & $1,300.2$ & $1,357.3$ & $1,309.1$ \\
\hline 2008 & $1,350.6$ & $1,452.5$ & $1,415.3$ & $1,550.7$ & $1,301.7$ & $1,359.2$ & $1,304.3$ \\
\hline 2009 & $1,309.3$ & $1,410.7$ & $1,315.9$ & $1,512.8$ & $1,270.2$ & $1,323.4$ & $1,292.6$ \\
\hline
\end{tabular}

Source: Federal Statistical Office.

A decomposition based on data of the Institute for Employment Research (IAB) indicates that mainly five components contributed to the reduction in working hours of salaried workers (see Figure 11): shorter weekly working hours, an increase in part-time employment, a reduction of paid overtime, a phasing-down of working-time accounts and a stronger use of short-time work. The most important component is associated with the strong use of short-time work in 2009, which amounts to minus 13.4 hours a year. The structural component of an increasing share of part-time employment contributed 7.5 hours to the reduction of working hours. Of great importance were shorter weekly working hours (minus 10.1 hours a year), a reduction of paid overtime (minus 7.9 hours a year), and a phasing down of working-time accounts (minus 7.0 hours a year). Though short-time work explains an important part of the strong reduction of working hours but it is not the major factor. About two third of the total change in working hours per year can be attributed to non-subsidised types of working time flexibility.

To sum up, several indicators show that the German labour market has been affected by the financial crisis. However, compared to earlier recessions and in contrast to many other countries in the Western world it has not shown a strong reaction in terms of aggregate employment and unemployment figures. Obviously firms have not immediately adjusted their work force in line with the 
decline in the demand for their products. This indicates that adjustment strategies on the firm level have mattered a lot in stabilising employment.

Figure 11

Changes in working hours per year in Germany 2009

(Yearly averages, changes in hours)

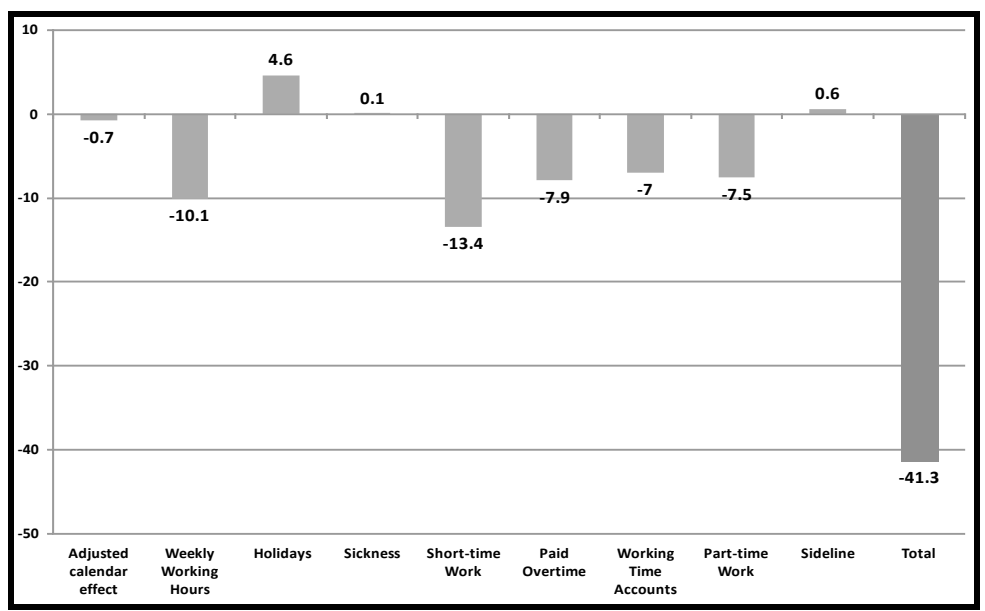

Source: Fuchs et al. 2010.

\section{STABILISING EMPLOYMENT ON THE FIRM LEVEL}

In general, firms can attain flexibility in different ways. They may adjust labour by hiring and firing workers or vary working hours as well as productivity per hour. In times of recession stabilising of employment on the firm level would then mean to avoid dismissals as far as possible and at the same time use internal mechanisms to maintain workers. An important distinction in this respect can be made between external numerical flexibility and internal numerical flexibility (Atkinson 1984; Atkinson/Meager 1986). ${ }^{6}$ External numerical flexibility refers to the adjustment of the number of workers. Although in Germany production significantly decreased as a consequence of the financial crisis firms avoid external adjustment to a large extent. Obviously, internal flexibility has mattered a lot in stabilising employment. There are two options to achieve internal numerical flexibility in a recession: One is to lower working hours of workers already employed within the firm and the other is to reduce at least

\footnotetext{
${ }^{6}$ Atkinson (1984) also notes that there can be two other types of flexibility. First, functional flexibility refers to the extent workers can be transferred to different activities and tasks within the firm. It can be attained by organisational changes and training workers. Second, wage flexibility means that wages are not negotiated on a collective level, e.g. by using assessment based pay systems or individual performance wages.
} 
temporarily productivity per hour. The first-mentioned is also known as working time flexibility, the latter as labour hoarding in a narrow sense.

In the following sections we will identify which types of internal numerical flexibility have played a role in stabilising the German labour market. We will also discuss the implications of internal numerical flexibility on the macro level and problems which may be associated with such a strategy. As already mentioned working time flexibility is one of the core options to stabilise employment. In some cases it might be regarded as an independent profit maximising strategy of firms (section 3.1). The firm's choices might be influenced by agreements on more centralised levels. In Germany negotiations between employers and work councils or between unions and employer's associations were leading to socalled "alliances for jobs" or company level pacts for employment. They may refer to adjustment in working hours as well as wages (section 3.2). Also legal institutions and public policies obviously influence the firms' decisions concerning the labour input. Especially short-time work has been a very important and widely used instrument to secure jobs, so we will discuss it in greater detail (section 3.3). Internal numerical flexibility has implications on the macro level because it influences labour utilisation. Therefore, the development of labour productivity needs to be analysed more deeply (section 3.4). In a further step we will discuss whether the obviously large use of internal numerical flexibility in German firms during the course of the crisis can be interpreted as labour hoarding. In addition we will ask for reasons for the firms' behaviour (section 3.5). To conclude we will discuss possible problems and side effects that might come along with the German way of dealing with the crisis (section 3.6).

\subsection{Working time flexibility}

Internal numerical flexibility is a potential alternative to external adjustment. In this respect working time flexibility plays a major role. Figure 11 already showed that in Germany working hours were reduced by several means. Three of them are going to be addressed in this section because they can be seen as independent decisions by firms and do not imply direct subsidies such as in the case of short-time work (see section 3.3). The section starts with the issue of overtime followed by working time accounts and weekly working hours.

\section{Working overtime}

In the German labour market overtime still plays an important role. In 2009, paid overtime represented 2.3 per cent of the labour volume. On average each employee worked 38.4 hours paid overtime a year. Paid overtime offers some flexibility to the firm, thereby showing a clear cyclical component. It is used more often in times of economic boom and less in times of recession. This can also be illustrated by considering the consequences of the financial crisis. 
Figure 12 depicts a strong reduction in paid overtime in particular in the $1^{\text {st }}$ quarter of 2009 and therefore almost at the peak of the crisis measured by the loss in GDP. However, the overall measurement of overtime is to some extent imprecise. While paid overtime can be well captured by the data, unpaid overtime is underreported in administrative data and surveys. Therefore cyclical variations of working hours might be underestimated in the available data.

While still being used to a considerable degree, paid overtime lost its importance during the last decade. For example, in 2001 paid overtime had a share of 3.5 per cent of the labour volume and employees even worked 59.4 hours paid overtime a year. The decrease in paid overtime can partly be attributed to the creation and use of measures of working time flexibility. For example, additionnal flexibility has been achieved by collective agreements concerning (cyclical) variations of working hours and the increasing use of working time accounts.

Figure 12

GDP and paid overtime in Germany

$1^{\text {st }}$ Quarter $2005-1^{\text {st }}$ Quarter 2010

(Growth rate and change in hours compared to the previous quarter in per cent)

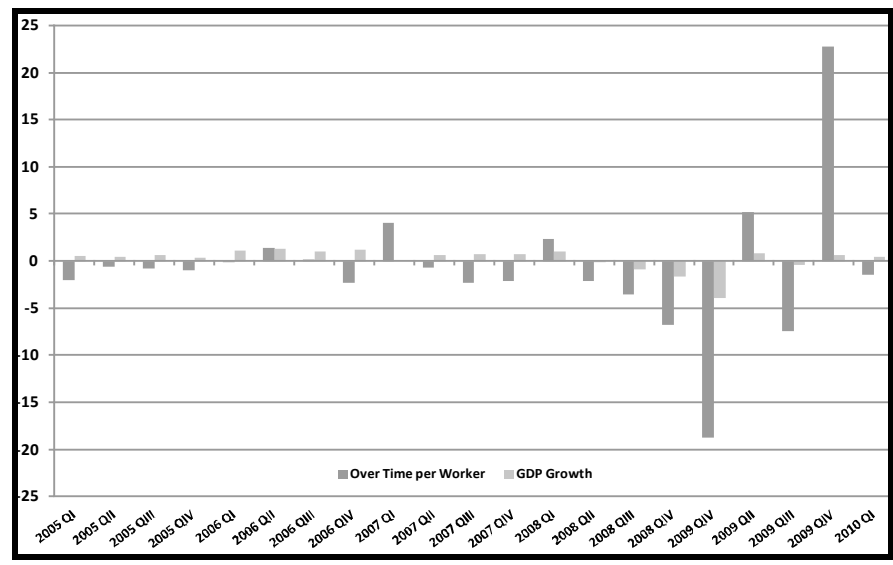

Source: Federal Statistical Office and IAB.

\section{Working time accounts}

According to Zapf/Brehmer (2010) 51 per cent of all German employees dispose of working time accounts. Therefore, working time accounts are increasingly used to deal with short-run fluctuations in demand (Bellmann/Gerner 2010). They allow for increasing working hours during times of high demand. The accounts act as a buffer stock which can be spent to reduce working time during periods of lower activity. In doing so, real labour costs are shifted from a period of high production activity to a period of low production activity. This 
guarantees income stability for workers although they are facing fluctuations of working hours.

IAB data show that such accounts played an important role as a buffer during the course of the financial crisis. Figure 13 illustrates changes on working time accounts between the $1^{\text {st }}$ Quarter of 2008 and the $1^{\text {st }}$ Quarter of 2010. Especially in the $4^{\text {th }}$ Quarter of 2008 and the $1^{\text {st }}$ Quarter of 2009 the accounts were phased down to a considerable extent. However, reductions went on further and there is evidence that some firms even allow accounts to be negative (Zapf/Brehmer 2010). In these cases employees will have to work longer hours in the period of economic recovery in order to compensate their debt in hours and to build up new assets.

Figure 13

GDP and working time accounts in Germany

$1^{\text {st }}$ Quarter $2005-1^{\text {st }}$ Quarter 2010

(Growth rate and change in hours compared to the previous quarter in per cent)

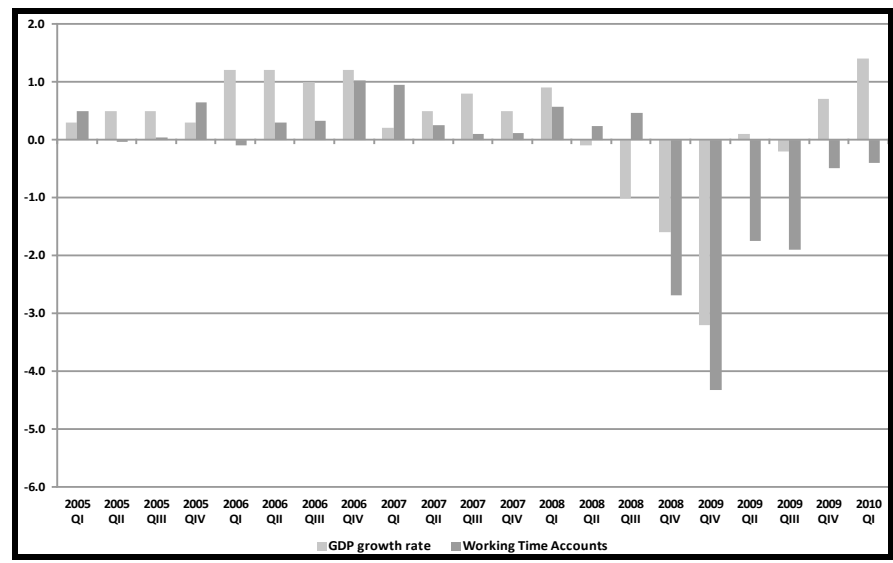

Source: Federal Statistical Office and IAB.

\section{Reduction of weekly working hours}

In Germany the length of weekly working hours depends largely on collective agreements. In general, firm-specific arrangements are oriented towards those regulations. But in recent years weekly working hours have become more flexible particularly in manufacturing. Collective agreements as well as firmspecific alliances for jobs allow longer working hours during peak periods of demand and shorter hours during recessions under the condition that the contracted working time is maintained on average over a defined period. Figure 14 illustrates the development of average weekly working hours during the period $1^{\text {st }}$ Quarter 2008 and $1^{\text {st }}$ Quarter 2010 depicting total employment as well as on full-time employment. Significant reductions of average weekly working hours 
took place in the $4^{\text {th }}$ Quarter of 2008 and the $1^{\text {st }}$ Quarter of 2009. The strongest reductions of average weekly working hours compared to the same quarter of the previous year can be observed between the $1^{\text {st }}$ Quarter 2009 and the $3^{\text {rd }}$ Quarter 2009.

The reduction of weekly working hours comes at an expense for workers, employers, and the state. Lower working hours imply lower taxes as well as fewer social security revenues. Workers experience lower gross and net wages and for employers lower hours are associated with a lower utilisation of capacities which will reduce their profits.

Figure 14

GDP and average weekly working hours in Germany

$1^{\text {st }}$ Quarter $2005-1^{\text {st }}$ Quarter 2010

(Growth rates and changes in hours compared to the previous quarter)

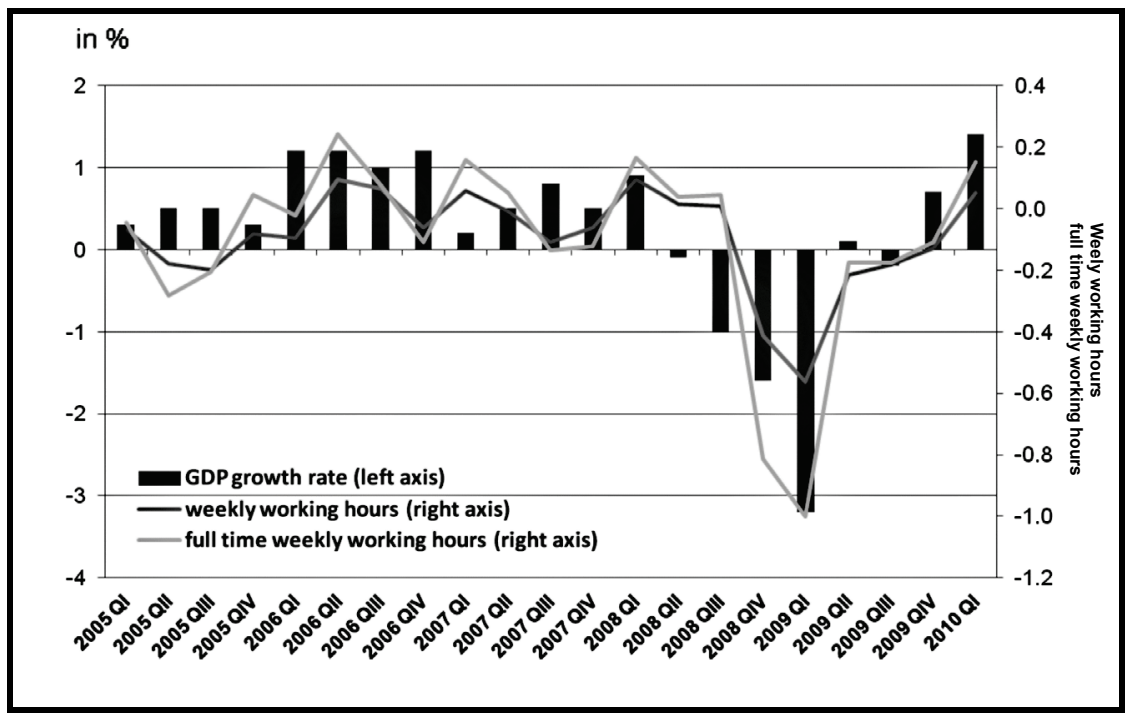

Source: Federal Statistical Office and IAB.

\subsection{Company-level pacts for employment}

Efforts on the company level to maintain jobs may be supported by the social partners. In the mid of the 1990s so-called company-level pacts for employment (or alliances for jobs) emerged in Germany. They aim at overcoming a company's crisis and at increasing the firms' competitiveness. Often opt-out clauses in agreements or cases of hardship are used by companies to implement such alliances. In most cases such pacts need the consent of the social partners. 
The German IAB Establishment Panel indicates that in 2009 approximately 16 per cent of all workers were employed in companies with alliances for jobs. In companies with 250 workers or more the share reached almost 50 per cent.

Company-level pacts for employment or opt-out clauses in collective agreements consist of a two-side agreement that may have different contents like flexible working hours, short-term reductions of working hours, suspensions of yearly bonuses, holiday pay or wage increases, and even wage cuts.

If workers make allowances concerning wages or working hours and contribute to a reduction of labour costs, firms may dispense redundancies and both parties can benefit from the agreement. This mutual effort can be seen as an act of reciprocity or an investment in a long-term employment relationship strengthening the ties between workers and employees.

Studies show that the way of implementing those pacts is most important for its success. The agreement has to be judged as a fair deal especially by the employees to avoid negative consequences for working morale (Okun 1981, Blinder/Choi 1990, Greenberg 1990, Howitt 2002). In general, wage reductions are more likely to be judged unfair than working time reductions.

Finding solutions for securing jobs on the basis of a social dialogue may also be supported by the state. Since the beginning of the crisis German regulations offer a more generous assessment base for unemployment benefits. It was decided that income reductions resulting from a temporary reduction of wages or working hours are not relevant for the calculation of unemployment benefit I (UB I). Instead the initial income will be the basis for UBI so workers would not suffer from lower benefits in case of redundancy. This facilitates the conclusion of alliances for jobs and also increases the willingness of workers to temporarily accept lower working hours without any wage compensation.

In order to increase the firms' competitiveness the parties may also arrange changes in the organization or the range of products. In many cases this is associated with additional training efforts. The IAB establishment panel reveals that in 2006 almost one quarter of alliances for jobs include training measures.

The effects of alliances for jobs are not clear-cut. Further studies show that there are positive employment impacts which are, however, statistically insignificant (Bellmann et al. 2008). But it should be mentioned that the reference period for the analyses was a period of economic boom which means that we do not know how far the results also hold for the recent crisis. The analyses further indicate that alliances for jobs initiate internal training. However, firms who already offered internal training to a large extent before arranging an alliance were the driving forces. 


\subsection{Short-time work as a subsidised working time reduction}

The state can also make working-time reductions more attractive and labour hoarding cheaper. The German short-time work (Kurzarbeit) is such a subsidy for working time reductions where the unemployment insurance partly compensates for workers' income losses and the costs of firms to maintain workers. The magnitude of savings on the side of the firm depends on the concrete features of the short-time work scheme. Important issues in this respect are the duration of benefits replacing the former wage and possible direct subsidies, e.g. concerning social security contributions. Germany is one of the countries with a long tradition of short-time work. At the moment there are three types of short-time work, whereof cyclical short-time work has been of major relevance in the recent crisis:

- Cyclical short-time work (Konjunkturelle Kurzarbeit) in case of a temporary, unavoidable loss of employment due to economic factors or to an unavoidable event.

- Transitional short-time work (Transfer-Kurzarbeit) in case of a permanent loss of employment due to re-structuring measures on the establishment level.

- Seasonal short-time work (Saison-Kurzarbeit) in case of non-productive times due to weather conditions.

The conditions for cyclical short-time work have been changed in the course of the crisis making it more attractive to companies by extending the maximum duration, giving financial support for training schemes and reducing social security contributions. The expenditures for those measures were part of the stimulus packages ${ }^{7}$. Table 3 offers information about the requirements of cyclical short-time work.

The benefits of short-time work schemes for firms are obviously similar to measures of internal flexibility. The additional advantage is that state subsidies reduce labour costs immediately. But it is important to understand that the costs of short-time work are not solely born by the state with respect to wage-related tax losses and the unemployment insurance with respect to benefit payments. Employees accept a reduction of their net income. Firms have to deal with a lower capital utilisation and they have to carry remaining costs such as social security contributions for the reduced working hours or the wage pay during vacation (Crimmann et al. 2009). For Germany, Bach/Spitznagel (2009) estimate that the remaining costs for firms amount to up to 35 per cent of the usual labour costs.

\footnotetext{
${ }^{7}$ For further information compare with Dietz et al. 2011.
} 
Table 3

Requirements for the use of cyclical short-time work and recent changes

\begin{tabular}{|c|c|c|}
\hline $\begin{array}{l}\text { Requirements } \\
\text { for use }\end{array}$ & Pre-crisis regulations (since 1997) & Recent Changes \\
\hline \multirow{4}{*}{$\begin{array}{l}\text { Significant unavoidable } \\
\text { loss of work }\end{array}$} & $\begin{array}{l}\text { Temporary loss of work due to economic } \\
\text { reasons. }\end{array}$ & No or minor changes \\
\hline & $\begin{array}{l}\text { Other options of internal flexibility need to be } \\
\text { utilized. }\end{array}$ & $\begin{array}{l}\text { January 2009: } \\
\text { Under certain conditions working time accounts } \\
\text { need not necessarily be reduced. }\end{array}$ \\
\hline & $\begin{array}{l}\text { At least one third of the staff must be } \\
\text { affected. }\end{array}$ & $\begin{array}{l}\text { February } 2009 \text { until March 2012: } \\
\text { Compensation can be granted even if the firm is } \\
\text { not able to provide full employment to at least } \\
\text { one jobholder. }\end{array}$ \\
\hline & $\begin{array}{l}\text { Estimated loss of income for the entire staff } \\
\text { of at least } 10 \text { p.c. }\end{array}$ & No or minor changes \\
\hline \multirow[t]{2}{*}{$\begin{array}{l}\text { Requirements } \\
\text { to the establishment }\end{array}$} & At least one regularly employed jobholder. & $\begin{array}{l}\text { No or minor changes } \\
\text { January 2009: } \\
\text { Under certain circumstances short-time work can } \\
\text { also be granted to agency workers. } \\
\end{array}$ \\
\hline & $\begin{array}{l}\text { Good chance that firm returns to regular } \\
\text { working hours. }\end{array}$ & No or minor changes \\
\hline \multirow{3}{*}{$\begin{array}{l}\text { Individual } \\
\text { requirements }\end{array}$} & Employment contract need to be maintained. & No or minor changes \\
\hline & $\begin{array}{l}\text { Short-time worker is obliged to accept job } \\
\text { offers from Federal Employment Agency. }\end{array}$ & No or minor changes \\
\hline & $\begin{array}{l}\text { Excluded are recipients of unemployment } \\
\text { benefits or subsistence allowances while } \\
\text { participating in publicly financed training } \\
\text { measures. }\end{array}$ & No or minor changes \\
\hline Notification & $\begin{array}{l}\text { Employers or works councils are obliged to } \\
\text { notify the estimated loss of work to the local } \\
\text { employment agency. }\end{array}$ & No or minor changes \\
\hline \multirow{3}{*}{$\begin{array}{l}\text { Social security } \\
\text { contributions }\end{array}$} & $\begin{array}{l}\text { Contributions are reduced to } 80 \text { p.c. for the } \\
\text { loss of working hours. }\end{array}$ & No or minor changes \\
\hline & \multirow[t]{2}{*}{ Employers have to bear the full amount. } & $\begin{array}{l}\text { February 2009: } \\
\text { Federal Employment Agency covers } 50 \text { p.c. of } \\
\text { the contributions for the loss of work. In case of } \\
\text { training during the loss of work, the agency } \\
\text { covers } 100 \text { p.c. of the contributions. Costs of } \\
\text { training measures can be reimbursed. }\end{array}$ \\
\hline & & $\begin{array}{l}\text { July } 2009 \text { until March 2012: Agency covers } 100 \\
\text { p.c. of the contributions for the loss of work from } \\
\text { the seventh month of short-time work. }\end{array}$ \\
\hline \multirow{4}{*}{ Duration of benefits } & \multirow{4}{*}{ Maximum duration of six months. } & January 2007 until June 2007: 15 months \\
\hline & & \begin{tabular}{|l} 
July 2007 until December 2008: 18 months \\
\end{tabular} \\
\hline & & \begin{tabular}{|l|} 
January 2009 until December 2009: 24 months \\
\end{tabular} \\
\hline & & \begin{tabular}{|l|} 
January 2010 until December 2010: 18 months \\
\end{tabular} \\
\hline \multirow{2}{*}{ Level of benefits } & $\begin{array}{l}60 \text { p.c. of the net wage loss due to shorter } \\
\text { hours. }\end{array}$ & No or minor changes \\
\hline & 67 p.c. with at least one dependent child. & No or minor changes \\
\hline
\end{tabular}

Source: Social Code III, as amended from time to time.

The companies can only benefit from the costly retention of workers if the reduction in working hours is temporary and if the affected workers do not leave the firm voluntarily. We also need to assume that laid-off workers may 
not return to their employer even in the absence of a short-time work scheme. Such "recalls" are used for significant shares of workers in countries where temporary layoffs are feasible (Kruppe/Mosley 1996).

In 2009 on average about 1.1 million people worked short-time (including cyclical, transitional and seasonal short-time work). This was the highest intensity of use -measured in number and shares of all employees- since the beginning of the 1990s (see Figure 15). At that time short-time work was used as an additional instrument of the social security network to dampen the structural consequences of German unification. The use of short-time work during the earlier recession from 2002 to 2003 was much lower than during the recent financial crisis.

Figure 15

Development of short-time work 1991 - 2010

(Total numbers)

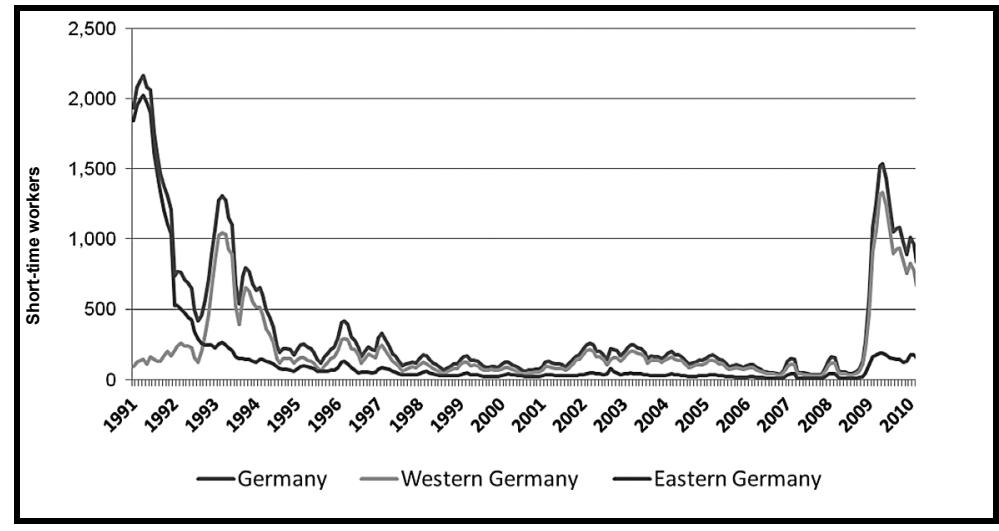

Source: Federal Employment Agency.

Cyclical short-time work is used most intensely in manufacturing and in Western Germany, in highly competitive sectors and regions with a previously good employment record. ${ }^{8}$ Therefore, the patterns of short-time work fit to our description of the initial economic situation and the nature of the crisis.

Most cyclical short-time workers are employed in firms with 200 and more employees. Furthermore, we can show that larger firms use cyclical short-time work more often than smaller firms. One reason is that it's easier for larger firms to adjust their employment and to use the instrument because of their economies of scale. Another reason is that larger firms in the manufacturing sector are more export-oriented - that's why they are more affected by the global

\footnotetext{
${ }^{8}$ See Crimmann et al. (2010) for more detailed information on cyclical short-time work.
} 
decline in sales due to the crisis. However, if smaller firms decide to use shorttime work the share of short-time workers within these firms is quite higher than in larger firms (Bechmann et al. 2010).

There is a clear indication that firms used short-time work as a means of partly financing working time reductions in the recent crisis. A mix of strategies should build a bridge over the crisis, making their workers return to their job on regular working hours.

Based on an average loss of 36 per cent of the working time the amount of short-time work corresponds to about 340.000 full-time employers in 2009. As some of the short-time workers are employed on a part-time basis, the calculated effect of short-time work on securing employment is likely to be slightly higher. Often full-time equivalents are put on a level with its impact on the labour market. But this equation overestimates the incremental employment effects of the programme. It fails to take windfall profits into consideration. A certain amount of displacement can take place, as both viable and non-viable firms are supported during the crisis (see section 3.5). In addition, it also assumes that the mere alternative to short-time work is non-employment and disregards that in some cases dismissals may not be avoided through short-time work but only postponed (Kruppe/Mosley 1996).

Since February 2009 the Federal Employment Agency will cover 100 per cent of social security contributions if short-time workers are trained at the same time. ${ }^{9}$ However, this combined instrument was not widely accepted by firms. Less than one $1 / 7$ of the establishments using short-time - mostly the bigger ones - had at least one short-time worker who took part in a subsidised training measure at the same time (Bechmann et al. 2010). There are several reasons for the comparatively low use of training measures. Due to the corresponding wage cuts workers often prefer leisure time instead of training. In general, it was difficult to find suitable training schemes which fit to the workers' needs as well as to the operating requirements of the firm. In addition, in July 2009 the government extended the full coverage of social security contributions to all shorttime work cases lasting longer than six months. Therefore, the financial incentive for firms to use the simultaneous measure of short-time work and training decreased relatively.

\subsection{Macroeconomic implications: Labour utilisation and labour productivity}

Having in mind the observation of a strong internal numerical flexibility in Germany it is important to evaluate what these adjustment processes meant for labour productivity. Figure 16 depicts the development of labour productivity

\footnotetext{
${ }^{9}$ Training measures must be certified by the Federal Employment Agency.
} 
per person and per hour as a measure of the utilisation of labour input. Labour productivity per hour has been higher than its per-person counterpart for most of the period. An important explanation for this is the persistent downward trend in total hours worked. As a consequence of the financial crisis both labour productivity per person and labour productivity per hour have decreased significantly to all-time lows. The pro-cyclical behaviour of labour productivity per person reflects the observation that employment adjusts less than output over the cycle. Time lags may be caused by labour market institutions like employment protection legislation as well as labour market imperfections both leading to increasing costs of hiring and firing. Another reason might be that workers produce less in times of recession and more in times of economic boom (de Koning 1989, Franz 2006).

Figure 16

GDP growth and labour productivity in Germany $2^{\text {nd }}$ Quarter $1991-2^{\text {nd }}$ Quarter 2010

(Percentage changes compared to the previous quarter, seasonally adjusted)

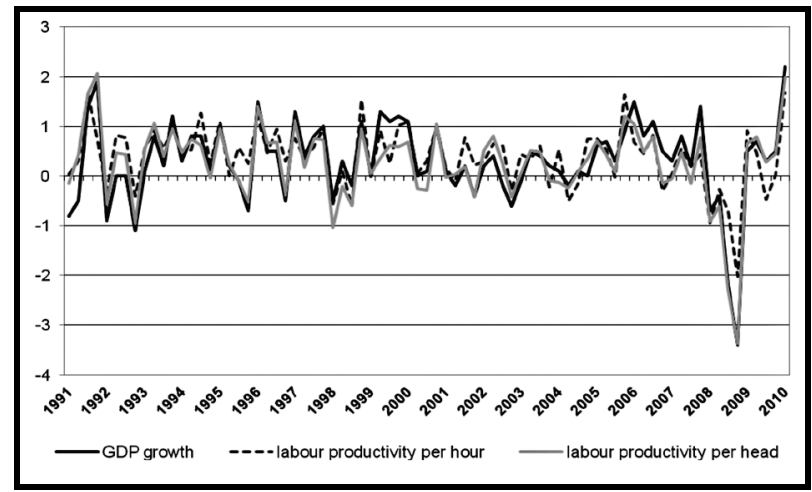

Source: Federal Statistical Office, IAB, own calculations.

With respect to the recent crisis we observe a strong decline of labour utilisation which is in line with our results concerning the observed mix of external and internal flexibility. The strong decrease of labour productivity per employee is not surprising bearing in mind that companies did not engage in layoffs in line with the decline in the demand for their products.

But as we see in Figure 16 labour productivity per hour also declined despite the strong drop in working hours.

Developments of labour productivity suggest a surprisingly strong level of labour hoarding which means that current employment is higher than required employment (Blankart 1973). However, the problem with this straightforward definition of labour hoarding is that the amount of required employment is hard 
to evaluate from an outsider's perspective. So the firm's adjustment of labour input might be a better way to approach the phenomenon of labour hoarding: we observe labour hoarding when firms do not immediately adjust labour input in line with the demand of their products and in particular allow their utilisation of labour to vary over the business cycle (Taylor 1982). This may again result in a reduction of total hours worked and a reduction of work intensity, or lead to a lower productivity per head and per working hour (Bosworth/Westaway 1990). Figure 16 shows that labour hoarding in terms of a lower utilisation of labour input has played a role in safeguarding jobs in Germany during the recent crisis.

Figure 17

Labour utilisation based on labour productivity per hour in Germany

$1^{\text {st }}$ Quarter 1991 - $2^{\text {nd }}$ Quarter 2010

(Cyclical component ${ }^{\star}$, seasonally adjusted)

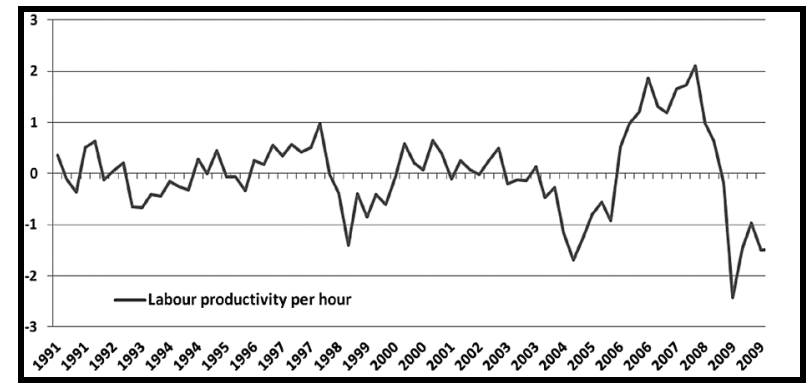

* Cyclical component calculated using a Hodrick-Prescott filter with the smoothing parameter $\lambda=1600$.

Source: Federal Statistical Office, IAB, own calculations.

Figure 18

Labour utilisation based on labour productivity per head in Germany

$1^{\text {st }}$ Quarter 1991 - $2^{\text {nd }}$ Quarter 2010

(Cyclical component*, seasonally adjusted)

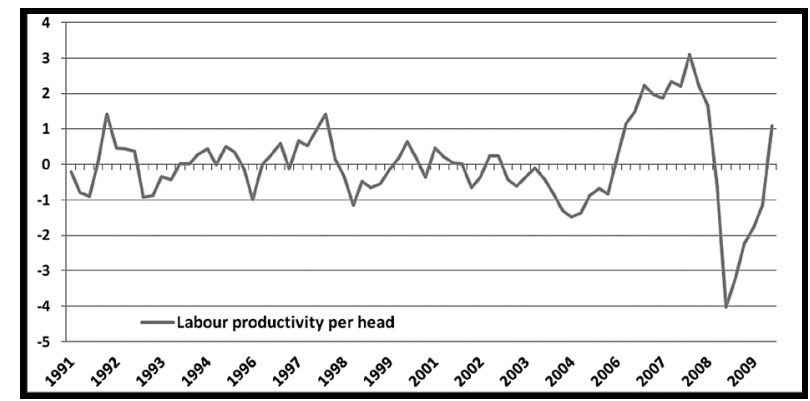

* Cyclical component calculated using a Hodrick-Prescott filter with the smoothing parameter $\lambda=1600$.

Source: Federal Statistical Office, IAB, own calculations. 
In order to assess the impact of the financial crisis on the labour market and particularly the role of labour hoarding, we need to ask how far below its longrun level labour utilisation is. In this respect labour productivity can be used as a proxy for labour utilisation. However, a linear trend is not necessarily a good measure of the long-run utilisation of the workforce (Felices 2003). A straight trend line might not properly represent the long-run behaviour of labour productivity. We assume that a time-varying trend is a more suitable measure for changes in labour productivity over time. A Hodrick-Prescott filter provides an estimation of such a time-varying trend (Hodrick/Prescott 1997). Figures 17 and 18 show the deviations between labour productivity and its fitted trend. Positive differences from the trend representing values above the zero line indicate an increasing labour intensity or labour hoarding below its long-run trend. Similarly, labour hoarding in terms of an underutilisation of the workforce occurs when negative differences from the trend can be observed. Since reunification this has happened several times (e.g. 1993 Quarters I-IV, 1994 Quarters II-III, 2004 Quarters I-2005 IV) but there has never been a negative deviation of labour utilisation from the long-term trend at the level which has been reached during the recent crisis.

Changes in labour productivity used as a proxy for labour utilisation cover variations of labour hoarding to a certain extent. But there are drawbacks which need to be mentioned. Interpreting changes in labour productivity per head or per hour over time as a more or less intensive use of labour input underestimates the changing influence of non-cyclical movements in labour utilisation. Labour productivity is also affected by other factors of production, e.g. cyclical movements in total factor productivity, changes in the capital stock and its utilisation, as well as varying returns associated with different inputs (Basu/Fernald 2000). Variations in labour productivity might also be affected by the measurement of GDP. A reliable measurement of labour productivity implies being able to measure labour input properly. Aggregate output includes only regular production or marketable output and more or less neglects other meaningful work which might be important for future production, such as painting the factory, machine maintenance or internal training. This kind of work which does not formally contribute to aggregate output can be of particular importance during recessions. In some industries even more labour input may be needed to sell the same amount of services, for example in logistics, or it may take the same amount of labour to serve a smaller number of people, e.g. in restaurants, theatres or cinemas. Labour productivity could therefore also decrease due to the specificities of certain tasks or due to problems in output measurement, and not solely because of firms hoarding labour. In addition, there are problems in estimating the level of productivity per hour and per head properly. We already pointed out that the measurement of working hours is to some extent imprecise which means cyclical variations in working hours might be underestimated in the avai- 
lable data. This would imply that labour productivity per hour is overestimated in recessions and underestimated in boom periods.

Nevertheless, using labour productivity as a proxy for labour utilisation reveals that labour hoarding played a not negligible role during previous recessions and did so in the recent crisis, too.

\subsection{Conditions favouring internal flexibility and labour hoarding}

As we have seen working time reductions play an important role in counteracting the impact of the crisis on the German labour market. In addition to these internal measures we observe a strong decline of labour productivity per head and per hour below the long-run trend on the macroeconomic level.

At first sight maintaining jobs at a level not necessary for the current production level (labour hoarding) is an economic anomaly. From a perspective of profit maximisation in a world with homogeneous labour and without transacttion costs labour hoarding at the establishment level can hardly be explained. Under these circumstances, an underutilisation of labour means that companies stand to the right of their labour demand curve, so they fail to minimise costs at a given production volume. Competition would cause these companies to disappear from the markets.

So we need at least to find plausible explanations for the firm's behaviour: What makes internal flexibility so attractive? And beyond that, why do German firms engage in labour hoarding, suffering from a strong decline of labour productivity instead of separating from a part of their workforce? ${ }^{10}$

To shed light on this behaviour we should remember that real-life markets are much more complex and companies' decisions on hiring and firing are made on a broader basis than just weighing up actual wage rates and marginal productivity (de Koning 1989). This is rational because a pure strategy of external flexibility implies various transaction costs (Arrow 1970, Brechling 1965, Bowers/Deaton/Turk 1982, Horning 1994). Firms will face search costs when demand for their goods rises again and they need to hire new employees. In addition, costs will be incurred for setting up the labour contract and conducting job training (Bentolila/Bertola 1990). Besides there are benefits of labour hoarding resulting from the employment relationship itself. If tasks are highly firm-specific the termination of an employment contract is accompanied by a loss of important firm-specific knowledge which will be time consuming and costly to regain (Oi 1962, Becker 1975, Williamson et al. 1975). Obviously these arguments will be more relevant for high-skilled workers with complex

\footnotetext{
${ }^{10}$ The following arguments hold for internal flexibility as well as for labour hoarding. For reasons of simplicity we refer to labour hoarding throughout the section.
} 
tasks than for low-skilled people engaged in routine jobs (Kruppe/Mosley 1996).

Moreover, labour contracts are incomplete by nature and informal rules or social norms play an important role for the effectiveness of labour relations. This becomes more and more important in knowledge societies where tasks are complex and input-output relations are difficult to monitor. Here, principalagent problems are difficult to handle by means of financial incentives or sanctions, and trust and reciprocity are important ways of enhancing work effort (Akerlof 1982, Fehr/Gächter 2000). These informal mechanisms need a longterm relationship to evolve and become stable (Buttler/Walwei 1993, Marsden 1995). If the employment contract becomes relational (Macneil 1974) which means that the labour relation itself has a value, the costs of lay-offs will increase further, resulting in an irreversible loss of firm-specific and relational capital. This does not only affect the specific employment contract - the loss of trust may spill over and destroy reciprocal behaviour on a broader basis among the remaining staff. In addition, the company's reputation as a reliable employer is weakened, which might induce quitting and hamper future recruitment (Okun 1981). In contrast, labour hoarding is an approach that is complementary to norms of reciprocity and trust, because it signals that firms are willing to invest in safeguarding a stable employment relationship. In doing so, a high level of work motivation can be sustained.

Besides these factors stemming from the employment relationship itself, there are other factors favourable to labour hoarding in Germany. They have to do with the initial labour market conditions before the crisis and the nature of the shock, with labour market institutions and with direct state intervention.

\section{The overall labour market situation at the beginning of the crisis}

There are more factors influencing the level of transaction costs, e.g. the overall labour market situation. When there has been a period of difficulties with respect to the supply of labour in specific sectors in the past, firms will expect long periods of vacancies and thus high recruitment costs. Under such circumstances transactions costs go up and labour hoarding becomes plausible up to a certain degree. In particular with regard to skilled workers there are incentives for labour hoarding because these are the workers that will be needed urgently during the (next) upswing (James/Thomas 1998).

The decision not to dismiss core workers may also reflect recent skill shortages in those regions or industries mainly hit by the crisis. Indeed the German economy, particularly manufacturing companies of Western Germany, experienced difficulties to recruit highly skilled labour during the last economic upswing. Examples for scarcities are engineers and other technical staff requiring an academic degree or an apprenticeship. So the companies are aware of an 
upcoming recruitment problem, expect increasing hiring costs in the future and thus may be willing to preserve jobs in these sectors and occupations. This is even more important because the crisis is especially affecting regions and sectors which have exhibited a comparatively good labour performance during the recent past: highly competitive and export-oriented manufacturing industries (Möller 2009). The German Vacancy Survey indicates that especially firms particularly affected by the crisis report skill shortages prior to the crisis (see Figure 19).

The more those companies expect a recovery of their orders, the more they are willing to maintain core workers. And they are also able to do so as many of the affected companies had earned good profits in the economic upswing. This is also indicated by strong positive deviations of labour productivity from its long-term trend during this period (see Figures 17 and 18). For this reason they are able to bear the costs of labour hoarding at least for some time without danger of bankruptcy.

Figure 19

Recruitment problems of German companies affected by the crisis by industries $4^{\text {th }}$ Quarter 2008 and $2^{\text {nd }}$ Quarter 2009

(in percentages)

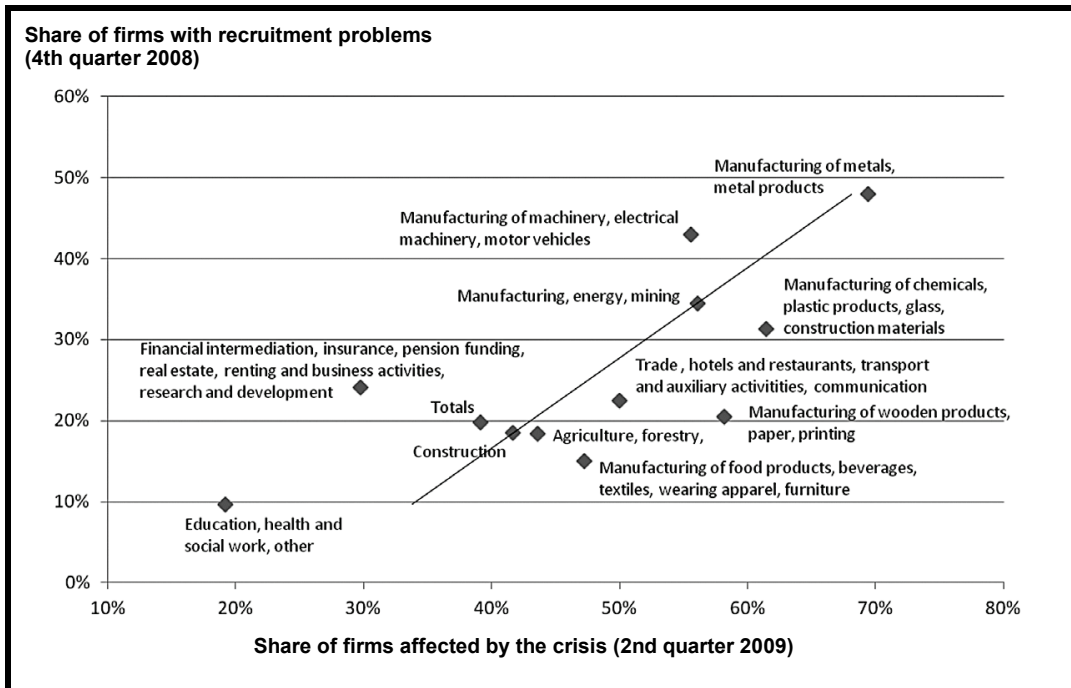

Source: IAB, Job Vacancy Survey.

\section{Wage moderation}

Since the year 2000 wages have increased only slowly in Germany. This wage moderation was further strengthened by the labour market reforms between 
2002 and 2005. As a consequence of these reforms the unemployed are willing to accept jobs at a lower wage level. For analysing the employment decision of firms, the development of labour productivity has to be weighed against the wage development. If productivity goes up there will also be room for wage increases without the need to lay off workers.

Figure 20 shows on an aggregated macroeconomic level that labour costs per hour increased only moderately and even did not exhaust the employment-neutral macroeconomic distributional scope resulting from changes in labour productivity. Especially during the last boom from 2005 to 2008 the development of labour costs per hour stayed well below the macroeconomic distributional scope. The wage development thus facilitated new recruitments and contributed to the increase in employment.

Figure 20

Development of labour costs* per hour in relation to the macroeconomic distributional scope $^{* *}, 1992-2009$

(Percentage changes compared to the previous year)

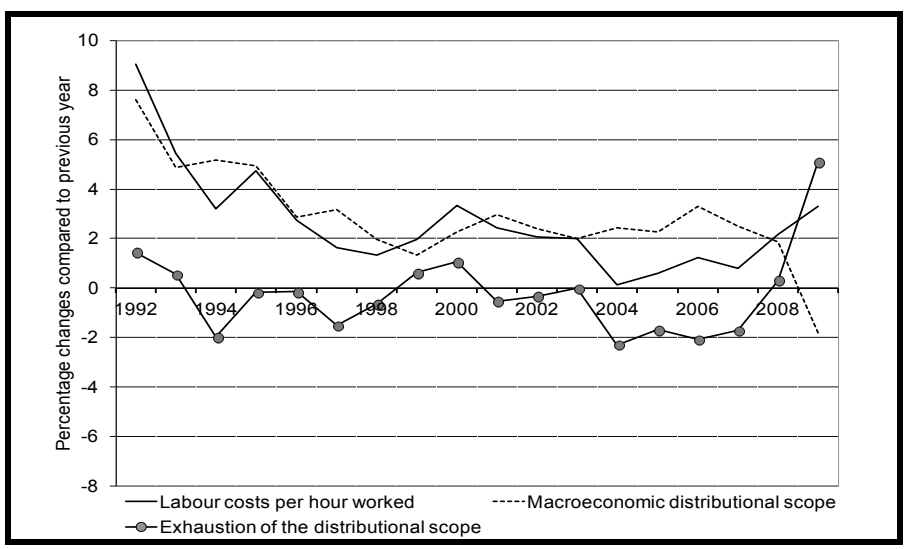

* Labour costs are measured in terms of gross wages plus employers' social security contributions.

** The macroeconomic distributional scope according to the definition of Sachverständigenrat (2007) marks the maximum changes of labour costs without any effects on employment.

Source: Gartner/Klinger (2010).

The ongoing wage moderation also improved the competitiveness of German companies on the world markets. While unit labour costs in the Euro zone and the OECD showed an upward trend the German unit labour costs remained quite stable during the last decade and even show periods of decreasing numbers falling behind the baseline of the year 2000. Again it is striking that the boom period from 2005 to 2008 was not accompanied by rising unit labour costs. 
With respect to the economic crisis wage moderation endowed the firms with resources for securing their staff and reduced the pressure on redundancies or on reducing labour costs (Boysen-Hogrefe/Groll 2010). Because labour hoarding comes along with a decline in productivity, a strong rise in unit labour costs and temporary over-utilisation of the distributional scope can be observed from the end of 2008 in Figures 20 and 21.

Figure 21

Development of real unit labour costs in Germany, the EU, and the OECD $1^{\text {st }}$ Quarter $2000-1^{\text {st }}$ Quarter 2010 (Index $2005=100$ )

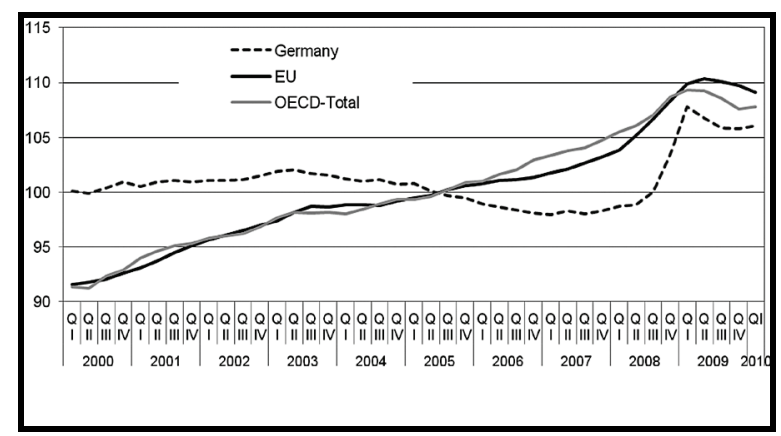

Source: OECD.

\section{Institutional features of the labour market}

When looking at the transmission of shocks from goods markets to the labour market we typically observe some kind of a time lag. Obvious reasons are institutional features of the labour market. The length of the delayed labour market response to shocks on the goods markets depends, for example, on the strictness of employment protection for standard work arrangements and the way more flexible work arrangements such as agency work or fixed-term contracts are legislated (see also section 2).

Germany is a country with a long tradition of social partnership and workers participation. Associated with this it provides workers with a high level of employment security. Compared to other OECD countries employment protection legislation is quite strict with respect to standard work arrangements while the deregulation of temporary work led to a decreasing index and contributed a more intense use of these work arrangements (see Venn 2009). Germany comes third in a ranking of the OECD countries according to the strictness of their protection of permanent workers against (individual) dismissals. Thus, to a certain degree labour hoarding is unavoidable on an institutionalised labour market like in Germany. 
Indeed, we observe different labour market reactions in an international comparison. Countries with weak employment protection like the United States and Ireland or with a comparatively large proportion of fixed-term contracts like Spain showed a quick and strong reaction with respect to employment. In contrast the labour market response in countries with strict employment protection like Germany, Austria or the Netherlands has remained fairly small bearing in mind the sharp decrease in GDP (see Figure 22).

Figure 22

GDP and employment in selected OECD countries, 2008 - 2009

(Growth rates compared to the previous year)

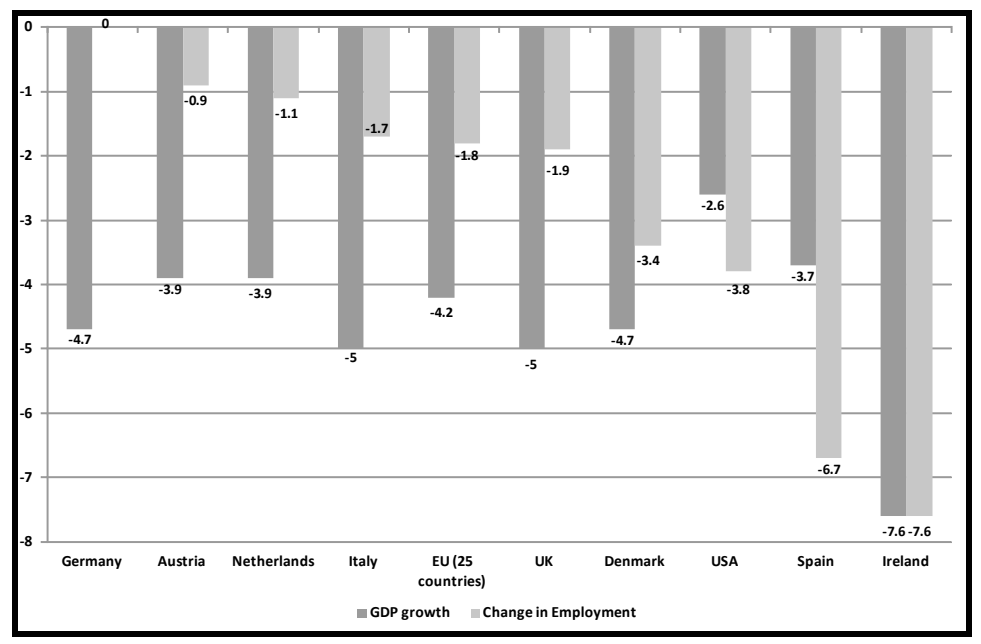

Source: Eurostat.

In Germany, employment protection implies stable employment relationships for core workers which were maintained during the financial crisis. On the other hand, the more flexible use of agency work offers some external flexibility. In addition, German companies established further functional equivalents for external numerical flexibility. New instruments of internal flexibility such as working time accounts at the establishment level allow for variations of working hours (see section 3.1).

In addition to employment protection and internal measures of flexibility the instrument of short-time work served as a stabiliser of employment relationships mitigating the transmission of the shock to the labour market. Although there is some access to short-time work for agency workers by now, it is the core workforce that benefits to a large degree. 


\section{Interim conclusion}

There are thus several reasons for labour hoarding that can be derived from an institutional perspective as well as from market reasons and the logic of modern employment relationships. These benefits of labour hoarding have to be weighed against its costs, which are associated with lower labour productivity and a corresponding increase in unit labour costs. So the price for labour hoarding is a decreasing competitive position of the firm on the goods market in the short run. An important factor for this consideration is how long the firm expects the decline in demand to last. Labour hoarding will be more favourable when companies are facing only short-term declines in production, while expectations of a deep and long-lasting decline increase the likelihood of lay-offs and make transaction cost arguments less important: labour hoarding tends to become inefficient. Output uncertainty is crucial in this respect and cannot really be avoided (de Koning 1989). If firms adjust their labour input to the levels of sales volume that may be achieved under favourable conditions, they run the risk of being left with unneeded workers. If they decide to reduce staff, they may be short of workers afterwards.

\subsection{Negative side-effects of the German miracle?}

Internal flexibility has the potential to secure core workers. But at the same time it creates a risk when it comes along with job freezes. In this case the expected level of new hires might be lower than it would have been otherwise. Labour market dynamics decrease and the employment intensity of growth is likely to be lower in the next upswing. Therefore, outsiders bear even more risks of human capital deviation while insiders in the core workforce are secure. This is especially a problem for less competitive workers such as long-term unemployed facing difficulties to enter the labour market.

Another side effect might stem from the high utilisation of short-time work. A crucial question for an assessment of short-time work is how far it could have been substituted by non-subsidized types of labour hoarding and how far displacement effects are of certain relevance. This question can, of course, not be answered by using macro data. There is also evidence that short-time work has partly contributed to labour hoarding. Nevertheless, firm data covering an earlier recession shows that short-time work was also used by firms which did not significantly expect an underutilisation of their capacities (Dietz et al. 2010).

This cannot at all be excluded in the case of the recent crisis especially with regard to the reforms leading to more generous short-time work schemes. Besides the financial incentives the new legislation also constitutes that other options of internal flexibility do not necessarily have to be exploited anymore before applying for short-time work (see Table 3). So there is no sequence of 
phasing down working time accounts before using short-time work anymore, but different measures of working time reductions may be used simultaneously. This increases the portfolio of strategies for firms and improves their ability to react to the crisis but it should also lead to a stronger adoption of the subsidies and may imply a crowding out of non-subsidised activities.

Companies decide about labour hoarding on a cost-benefit ratio which in general does not include social costs of labour hoarding. Additional costs for the public may result, e.g. if short-time workers will be dismissed later on anyway or firms could have done without public aid.

Indeed firms not expecting a considerable decrease of sales used short-time work in the first six months of 2009 (see Table 4). A remarkable finding is that within this group establishments using short-time work are more likely to have steady or increasing levels of employment. Furthermore the biggest part of them expected no significant change in employment from June 2009 to June 2010 (Table 5). Of course, there might be reasons why these firms used short-time work in times of economic difficulties. E.g., certain parts of those companies may have been strongly affected by the crisis whereas others are still doing well. But also in these cases, the state should check whether the firm itself should be responsible for the necessary adjustments according to the principle of subsidiarity.

\section{Table 4}

Share of establishments with short-time work in the first six months of 2009 , by subgroups

\begin{tabular}{|c|c|c|}
\hline $\begin{array}{c}\text { Sales expectancies in } \mathbf{2 0 0 9} \\
\text { compared to } \mathbf{2 0 0 8}\end{array}$ & $\begin{array}{c}\text { Change of employment from 2008 } \\
\text { to 2009 }\end{array}$ & Share \\
\hline \multirow{2}{*}{ Steady or increasing sales } & Steady or increasing & $20 \%(+/-5.5 \%)$ \\
\cline { 2 - 3 } & Decreasing & $12 \%(+/-4.5 \%)$ \\
\hline \multirow{2}{*}{ Decreasing sales } & Steady or increasing & $34 \%(+/-6.0 \%)$ \\
\cline { 2 - 3 } & Decreasing & $34 \%(+/-6.0 \%)$ \\
\hline
\end{tabular}

Note: Weighted shares with estimated $95 \%$ confidence intervals for the number of establishments (taken from Fischer et al. (2008, p. 37). Only establishments with information about sales expectancy, employment in 2008 and 2009, and use of short-time work are considered (6\%+/-0.5 of all observed establishments in 2009).

Source: Stops (2010), IAB Establishment Panel.

However, most firms using short-time work expected decreasing sales. But not all of them lost employment between 2008 and 2009. The shares of establishments using short-time work and expecting decreasing sales with increased or steady employment and of those with a decline in employment were equal. This may suggest that short-time work has an impact: probably there would have been even more lay-offs without the existence of the scheme. Neverthe- 
less, a considerable part of these firms expects a further decline in employment from June 2009 to June 2010 (Table 5). This means that in 2009 the use of short-time work alone did not ensure positive employment expectancies of the corresponding firms.

To investigate the employment effects of short-time work a counterfactual situation would be needed. This means that firms which have used short-time work would have to be compared with "similar" firms in statistical terms which have not used the instrument. Given the data for Germany this is by no means an easy task - also because the intensity of utilisation on the firm level is not known. Nevertheless, Bellmann/Gerner (2010) made an attempt by using the German IAB Establishment Panel. However, they did not find any clear evidence for employment impacts of short-time work.

\section{Table 5}

Share of establishments with short-time work in the first six months of 2009 , by subgroups

\begin{tabular}{|c|c|c|}
\hline $\begin{array}{c}\text { Sales expectancies in 2009 } \\
\text { compared to 2008 }\end{array}$ & $\begin{array}{c}\text { Expectancies in changes of } \\
\text { employment from June 2009 } \\
\text { to June 2010 }\end{array}$ & Share \\
\hline \multirow{3}{*}{ Steady or increasing sales } & Increasing & $3 \%\left(^{*}\right)$ \\
\cline { 2 - 3 } & Steady & $27 \%(+/-5.5 \%)$ \\
\hline \multirow{3}{*}{ Decreasing sales } & Decreasing & $3 \%\left(^{*}\right)$ \\
\cline { 2 - 3 } & Increasing & $6 \%(+/-3.8 \%)$ \\
\cline { 2 - 3 } & Steady & $32 \%(+/-6.0 \%)$ \\
\cline { 2 - 3 } & Decreasing & $30 \%(+/-6.0 \%)$ \\
\hline
\end{tabular}

Note: Weighted shares with estimated 95\% confidence intervals for the number of establishments (taken from Fischer et al. (2008, p. 37).

* Number of establishments observed is too small. Only these establishments with information about sales expectancy, expectancies in changes of employment from June 2009 to June 2010, and use of short-time work are considered ( $5 \%+/-0,5$ of all establishments).

Source: Stops (2010), IAB Establishment Panel.

We conclude at this stage that it is not really known to what extent shorttime work has really stabilised employment in Germany, but there are hints for positive impacts: nearly half of the establishments with negative sales expectancies and using short-time work at the same time keep their level of employment. It should also not be concealed that the use of short-time work seems to be almost independent from the economic situation of the establishment. Even firms with positive sales expectancies used short-time work. In order to minimise windfall profits, one could think about more specific conditions for the use of short-time work. Especially better targeting seems to be an issue: one option would be to differentiate between firms suffering heavily from the crisis and firms being only marginally affected. Regulations could offer more generous subsidies and an easier access for the first group and less favourable conditions 
to the latter. The revised legislations in 2009 addressed heavily affected companies (defined as long-term users) by fully subsidising social security contributions. One may think of complementary regulations taking the (expected) economic situation of a firm into account. Nevertheless, there is a problem at that point in time when the decision for or against using short-time work has to be made: neither the firm nor the government knows whether the firm's negateve business expectations become true. One solution could be a combination of short-time work with a clause for repayment in the case of an unexpected better economic situation from an ex-post perspective.

\section{CONCLUSIONS}

Although the German economy was affected strongly by the financial crisis the labour market response was quite weak. This is true in comparison to earlier recessions as well as with respect to the developments in other countries during the recent crisis. As we have seen there is no single explanation for the stability of the German labour market during the course of the crisis. First of all, the worldwide economic crisis reached Germany when the labour market was in good shape. This positive development on the labour market was not only driven by a strong economic boom but it was also due to wage moderation and labour market reforms causing a more employment-intensive economic growth.

In addition the nature of the crisis was not structural but Germany experienced a strong cyclical demand shock. Particularly the manufacturing sector with highly competitive firms often situated in prospering regions in the southwestern part of Germany with a good overall labour market performance was heavily hit by the crisis. Other regions with higher unemployment rates have not been affected that much by the shock. In some of them employment even increased further despite the crisis due to a stronger service sector and the fiscal stimulus packages of the German government. These asymmetric consequences of the crisis turned out to be advantageous for the German labour market because existing labour market disparities were not fortified.

A lot of firms affected by the crisis had experienced skills shortages during the last boom period and thus companies and workers had a joint interest to stabilise their employment relations even in times of lowering demand. The economic upswing with high profits and high working hours endowed them with the resources to apply internal adjustment strategies like a phasing down of working time accounts or a decrease of labour productivity to secure the jobs of the core workforce. Layoffs occurred, too, but they affected the contingent workforce to a higher degree as the drop in agency work shows. So, the protection of the core workforce was also facilitated by the recent deregulation of temporary work arrangements which serve as an additional source of external numerical flexibility in the firm's portfolio of adjustment strategies. 
To a considerable degree firms engaged in labour hoarding in terms of not adjusting the number of employees in line with shifts of demand for their products. It is important to understand that the firms' decisions for labour hoarding are in line with profit maximising strategies and were not directly induced by public policy, although the strong tradition of social partnership on the German labour market has played an important role. As internal ways of flexibility were facilitated by job alliances and company level pacts for employment, a culture of social consensus on the collective level served as an important basis for good and sustainable solutions at the firm level.

Non-subsidised forms of working time reductions or labour hoarding were complemented by public subsidies in the form of short-time work. At the beginning of the crisis the conditions for short-time work became more attractive to firms. This has served as a political and psychological signal that the government is willing to support the firms in their efforts to secure jobs. To strengthen short-time work helped stabilising employment and preventing unemployment to rise.

But internal measures of flexibility as well as short-time work do have their limitations. They are not costless, as they imply lower profits for companies, lower wages for workers and higher budget deficits for the government - at least for a limited period of time. This reveals that such measures can only bridge a short-time crisis. There is only a reason to maintain jobs when firms have positive future expectations concerning increasing demand and profits. In a more structural crisis a larger number of layoffs would be unavoidable. In addition public subsidies like short-time work would run the risk of postponing structural change by securing non-viable firms. Workers might stick to their jobs too long and decrease their employment prospects. So the structure of the crisis and the competitiveness of the German firms were crucial pre-conditions for the effectiveness of adjustment processes on the firm level.

These considerations also imply that the specific structure of the economy and the nature of the shock have to be analysed in detail before transferring German solutions to other countries. They also hint to the general point that labour market policy might help to mitigate the consequences of an economic shock but it is not able to address the structural problems underlying an economic shock. The economic recovery and the stabilisation of the employment situation have to be grounded on a real recovery of the goods markets.

But also with respect to the favourable conditions for labour hoarding in Germany some open questions remain with respect to the effects of short-time work. In general the firms' decisions on the use of short-time work will ignore its social costs. Additional costs for the state may result, e.g. if short-time workers are dismissed later on anyway or if firms could have done without public 
aid. Labour market policy should aim to minimise these costs and restrict access to the "right" companies.

To sum up, the German miracle consists of several ingredients. The labour market benefited from the advantageous interplay of the initial conditions and the structure of the crisis. Measures counteracting the crisis are evidence of a good team work on different levels of the labour market. Employers, workers, social partners and the state were willing to contribute to securing jobs. Their interplay followed the principle of subsidiarity. The firm level was endowed with a high freedom to handle working conditions in a flexible way - of course within legal boundaries. This may have positive effects in the longer run because mutual agreements on measures to save jobs can strengthen the employment relation and become the basis for a long run and productive relationship. Social partnership supported these arrangements on the firm level which were finally complemented by the extension of the short-time work scheme. Although these joint efforts are an important explanation for the successful labour market adjustments one has to be aware of possible distortions triggered by state policies. As we pointed out there is some evidence that short-time work crowded out non-subsidised adjustments on the firm-level. This indicates the need for an efficient targeting procedure for public subsidies to firms.

\section{REFERENCES}

AKERLOF, G. A. (1982): Labour Contracts as Partial Gift Exchange, in: Quarterly Journal of Economics, Vol. 84, 488500.

ANTONI, M.; JAHN, E. J. (2009): Do changes in regulation affect employment duration in temporary help agencies? In: Industrial and Labor Relations Review, 62 (2), 226-251.

ARROW, K. J. (1970): The Organization of Economic Activity: Issues Pertinent to the Choice of Market versus Nonmarket Allocation, in: R. H. Haveman and J. Margolis (eds.): Public Expenditures and Policy Analysis, 59-73.

ARLT, A.; DIETZ, M.; WALWEI, U. (2010): Winds of change: Work arrangements in Germany, mimeo.

ATKINSON, J. (1984): Flexibility, Uncertainty and Manpower Management, IMS Report, No. 89, Institute of Manpower Studies, Brighton.

ATKINSON, J.; MEAGER, N. (1986): Changing Working Patterns: How companies achieve flexibility to meet new needs, Institute of Manpower Studies, National Economic Development Office, London.

BACH, H.-U.; SPITZNAGEL, E. (2009): Kurzarbeit: Betriebe zahlen - und haben etwas davon, IAB-Kurzbericht 17/2009. 
BASU, S.; FERNALD, J. (2000): Why is productivity procyclical? Why do we care?, NBER Working Paper Series, No. 7040.

BECHMANN, S.; DAHMS, V.; FISCHER, A.; FREI, M.; LEBER, U. (2010): 20 Jahre Deutsche Einheit - Ein Vergleich der west- und ostdeutschen Betriebslandschaft im Krisenjahr 2009 - Ergebnisse des IAB-Betriebspanels 2009, IAB-Forschungsbericht, 06/2010.

BECKER, G. (1975): Human Capital: A Theoretical and Empirical Analysis, with Special Reference to Education. New York: Columbia University Press, NBER.

BELLMANN, L. (2010): Erwerbstätigkeit und Arbeitslosigkeit in Deutschland. In: B. Badura, H. Schröder, J. Klose and K. Macco (eds.), Fehlzeiten-Report 2010. Vielfalt managen: Gesundheit fördern - Potenziale nutzen. Zahlen, Daten, Analysen aus allen Branchen der Wirtschaft, Berlin: Springer, 83-90.

BELLMANN, L.; GERNER, H.-D. (2010): Economic Crisis, Rising Unemployment and Policy Responses. Nuremberg: Paper prepared for the IZA/ OECD Workshop. Paris 8./9. February 2010

BELLMANN, L.; GERLACH, K.; MEYER, W. (2008): Company-level pacts for employment. In: Jahrbücher für Nationalökonomie und Statistik, 228 (5/6), 533553.

BENTOLILA, S.; BERTOLA, G. (1990): Firing Costs and Labour Demand: How Bad Is Eurosclerosis?. Review of Economic Studies, Vol. 57, 381-402.

BLANKART, B. (1973): Arbeitskräftenachfrage im Konjunkturablauf - das Problem des temporären Hortens von Arbeitskräften, Zeitschrift für Volkswirtschaft und Statistik, 109 (2), 171-185.

BLINDER, A. S.; CHOI, D. H. (1990): A Shred of Evidence on Theories of Wage Stickiness, in: Quarterly Journal of Economics, Vol. 105 (Nov.), 1003-1015.

BOSWORTH, D.; WESTAWAY, T. (1990): Labour Hoarding, and Recorded Unemployment in OECD Countries, in: J. Muysken and C. de Neubourg (eds.): Unemployment in Europe. London, Macmillan, 150-164.

BOWERS, J.; DEATON, D.; TURK, J. (1982): Labour Hoarding in British Industry, Oxford: Blackwell.

BOYSEN-HOGREFE, J.; GROLL, D. (2010): The German Labour Market Miracle, National Institute Economic Review 2010, Vol. 214, 38-50.

BRECHLING, F. P. R. (1965): The Relationship between Output and Employment in British Manufacturing Industries, in: Review of Economic Studies, Vol. 32, 187-216.

BUTTLER, F.; WALWEI, U. (1993): Employment Security and Efficiency: Assumptions in the Current Debate and Empirical Evidence for West Germany, 255266.

CAZES, S.; VERICK, S.; HEUER, C. (2009): Labour market policies in times of crisis, ILO Employment Working Paper No. 35.

CRIMMANN, A.; MÖLLER, J.; STOPS, M.; WALWEI, U. (2009): Kurzarbeit: Wann und wie lange lohnt sie sich? In: IAB-Forum, No. 2, 104-111. 
CRIMMANN, A.; ZIEGLER, K.; ELLGUTH, P.; KOHAUT, S.; LEHMER, F. (2009): Forschungsbericht zum Thema "Arbeitnehmerüberlassung". Endbericht zum 29. Mai 2009. Bundesministerium für Arbeit und Soziales. Forschungsbericht Arbeitsmarkt, 397, Nürnberg.

CRIMMANN, A.; WIEßNER, F.; BELLMANN, L. (2010): The German worksharing scheme. An instrument for the crisis. ILO Conditions of Work and Employment Series, 25, Geneva.

DE KONING, J. (1989): Labour Hoarding in Dutch Manufacturing Industry, De Economist, Vol. 137, 155-172.

DIETZ, M.; STOPS, M.; WALWEI, U. (2010): Safeguarding jobs through labor hoarding in Germany. In: K. F. Zimmermann and C. Wey (eds.), The economy, crises, and the labor market. Can institutions serve as a protective shield for employment?, Applied Economics Quarterly Supplement, Vol. 61, 125-149.

DIETZ, M.; STOPS, M.; WALWEI, U. (2011): Safeguarding jobs in times of crisis lessons from the German experience. (International Institute for Labour Studies. Discussion paper, 207), Genf, 67 S.

DUNN, E. S. (1960): A statistical and analytical technique for regional analysis, in: Papers of the Regional Science Association, Vol. 6, 97-112.

FAHR, R.; SUNDE, U. (2009): Did the Hartz Reforms speed-up the matching process? A macro-evaluation using empirical matching functions. In: German Economic Review 10 (3), 284-316.

FEHR, E.; GÄCHTER, S. (2002): Reziprozität und Ökonomie Implikationen reziproken Verhaltens für den Arbeitsmarkt. In: U. Blien and J. Möller (eds.), Europäische Arbeitsmärkte und Arbeitsmarkttheorie. Beiträge zur 11. Jahreskonferenz der European Association of Labour Economists (EALE) in Regensburg, (Beiträge zur Arbeitsmarkt- und Berufsforschung, 254), Nürnberg, 57-75.

FELICES, G. (2003): Assessing the extent of labour hoarding. Bank of England Quarterly Bulletin.

FISCHER, G.; JANIK, F.; MÜLLER, D.; SCHMUCKER, A. (2008): The IAB establishment panel - from sample to survey to projection. FDZ-Methodenreport, 01/2008.

FRANZ, W. (2006): Arbeitsmarktökonomik, Berlin: Springer.

FRICK, A.; WIRZ, A. (2005): Wirksamkeit der Kurzarbeitsregelung in der Rezession 2001-2003. seco Publikation - Arbeitsmarktpolitik, Vol. 13.

FUCHS, J.; HUMMEL, M.; KLINGER, S.; SPITZNAGEL, E.; WANGER, S.; ZIKA, G. (2010): Prognose 2010/2011: Der Arbeitsmarkt schließt an den vorherigen Aufschwung an, IAB-Kurzbericht 18/2010.

FUCHS, J.; HUMMEL, M.; KLINGER, S.; SPITZNAGEL, E.; WANGER, S.; WEBER, E.; ZIKA, G. (2011): Neue Arbeitsmarktprognose 2011: Rekorde und Risiken, IAB-Kurzbericht, 07/2011.

GARTNER, H.; KLINGER, S. (2008): Ein janusköpfiger Aufschwung: Beschäftigungsgewinne und Polarisierung. In: WSI-Mitteilungen, 61 (8), 439-446. 
GARTNER, H.; KLINGER, S. (2010): Verbesserte Institutionen stützten den Arbeitsmarkt in der Wirtschaftskrise, Wirtschaftdienst 90 (11), 728-734.

GREENBERG, J. (1990): Employee Theft as a Reaction to Underpayment Inequity: The Hidden Cost of Pay Cuts, in: Journal of Applied Psychology, 75 (5), 561-568.

HECKMANN, M.; KETTNER, A.; PAUSCH, S.; SZAMEITAT, J.; VOGLER-LUDWIG, K. (2009): Unternehmensbefragung im II. Quartal 2009: Wie Betriebe in der Krise Beschäftigung stützen, IAB-Kurzbericht, 18/2009.

HODRICK, R. J.; PRESCOTT, E. C. (1997): Postwar US business cycles: An empirical investigation. Journal of Money, Credit and Banking, 29 (1), 1-16.

HOHENDANNER, C. (2010): Befristete Arbeitsverträge zwischen Aufund Abschwung: Unsichere Zeiten, unsichere Verträge?, IAB-Kurzbericht, 14/ 2010.

HORNING, B. (1994): Labour hoarding and the business cycle, International Economic Review, Vol. 35, 87-100.

HOWITT, P. (2002): Looking Inside the Labor Market: A Review Article, in: Journal of Economic Literature, Vol. 40 (March), 125-138.

JAMES, J. A.; THOMAS, M. (1998): Labor Hoarding and Selective Retention of Skilled Workers in U.S. Industry in the Late Nineteenth-Century: The Workers' Perspective (with M. Thomas). In: C. Nunez (ed.), The Microeconomic Analysis of the Household and the Labor Market, Proceedings of the Twelfth International Economic History Congress, Madrid: Fundacion Fomento de la Historia Económica.

KETTNER, A.; REBIEN, M. (2007): Soziale Arbeitsgelegenheiten Einsatz und Wirkungsweise aus betrieblicher und arbeitsmarktpolitischer Perspektive, IABForschungsbericht, 02/2007.

KLINGER, S.; ROTHE, T. (2010): The impact of labour market reforms and economic performance on the matching of short-term and long-term unemployed. IAB Discussion Paper, 13/2010.

KOCH, S.; KRUG, G.; STOPS, M. (2009): Zur Bedeutung von öffentlicher Arbeitsvermittlung und Beratung in der Arbeitsmarktkrise. In: Sozialer Fortschritt, 58 (11), 241-248.

KRUPPE, T. (1996): Employment stabilisation through short-time work. In: G. Schmid, J. O'Reilly and K. Schömann (eds.), International handbook of labour market policy and evaluation, Cheltenham u.a.: Elgar, 594-622.

KRUPPE, T.; MOSLEY, H. (1996): Short-time work in structural adjustment european experience. In: European Journal of Industrial Relations, 2 (2), 131-151.

MACNEIL, I. (1974): The many futures of contracts. Southern California Law Review, Vol. 47, 691-816.

MARSDEN, D. (1995): Deregulation or Cooperation? The Future of Europe's Labour Markets, in: Labour - Special Issue 1995, 67-91.

MÖLLER, J. (2009): The German labour market response in the world recession de-mystifying a miracle, Journal for Labour Market Research, Vol. 42, 325-336. 
OI, W. Y. (1962): Labor as a Quasi-Fixed Factor of Production, Journal of Political Economy, Vol. 70, 538-555.

OKUN, A. M. (1981): Prices and Quantities: A Macroeconomic Analysis, Washington: The Brookings Institution.

ROTHE, T. (2010): Tägliche Dynamik auf dem deutschen Arbeitsmarkt. Wirtschaftsdienst, Vol. 90, 64-66.

SACHVERSTÄNDIGENRAT ZUR BEURTEILUNG DER GESAMTWIRTSCHAFTLICHEN LAGE (2007): Das Erreichte nicht verspielen, Jahresguta-chten 2007/08, Wiesbaden.

SCHWENGLER, B.; LOIBL, V. (2010): Beschäftigung, Arbeitslosigkeit und Kurzarbeit: Aufschwung und Krise wirken regional unterschiedlich, IAB-Kurzbericht, 01/2010.

STOPS, M. (2010): Deutschland: Arbeitskräftehorten als Schutzschirm in der Krise, bei: Jahrestagung der Gesellschaft für Sozialen Fortschritt e.V. "Globalisierung Krise - Sozialpolitik", Gesellschaft für sozialen Fortschritt e.V. und Evangelische Akademie Loccum, (Presentation at 05.10.10).

TAYLOR, J. (1982): The Theory and Measurement of Labour Hoarding, Applied Economics, Vol. 14, 591-601.

VENN, D. (2009): Legislation, Collective Bargaining and Enforcement: Updating the OECD employment protection indicators, OECD Working Paper No. 89.

WILLIAMSON, O. E.; WACHTER, M.; HARRIS, J. (1975): Understanding the Employment Relation: The Analysis of Idiosyncratic Exchange, in: The Bell Journal of Economics, Vol. 6, 250-278.

ZAPF, I.; BREHMER, W. (2010): Arbeitszeitkonten haben sich bewährt, IABKurzbericht 22/2010. 